$\begin{array}{cc}\text { Tür Coğrafya Dergisi } & \text { Turkish Geographical Review } \\ \text { Basıli ISSN 1302-5856 } & \text { ww.tcd.org.tr }\end{array}$

\title{
Küre Dağlarının Kastamonu iklimi üzerindeki etkileri
}

\section{Effects of the Kure Mountains on the climate of Kastamonu}

\author{
Selahi Coşkun *a \\ a Inönü Üniversitesi, Fen Edebiyat Fakültesi, Coğrafya Bölümü, Malatya, Türkiye.
}

ORCID: S.C. 0000-0003-4047-2064

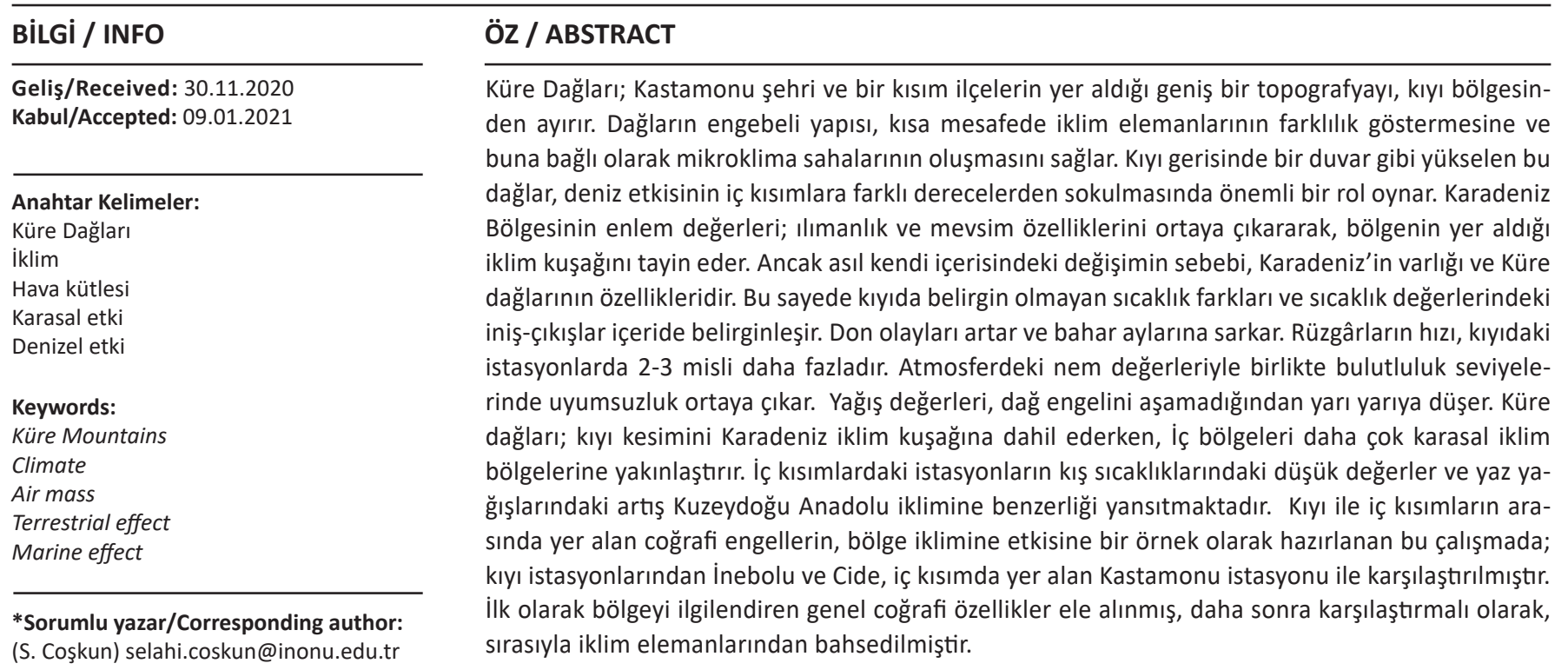

DOI: $10.17211 /$ tcd. 833701

\section{Athf/Citation:}

Coşkun, S. (2021). Küre Dağlarının Kastamonu iklimi üzerindeki etkileri. Türk Coğrafya Dergisi, (77), 37-52. https://doi.org/10.17211/tcd.833701
Küre Mountains extricates a large topography of the Kastamonu province and some districts from the coastal region. The rugged structure of the mountains enables the climate elements to differ in a short distance and as a result, microclimate fields are formed. These mountains rising like a wall behind the shore play a significant role in introducing the sea effect to the interior to different degrees. The latitude values of the Black Sea Region reveal the temperate and seasonal characteristics and determine the climate zone in which the region is located. However, the main reason for the change within itself is the existence of the Black Sea and the characteristics of the Küre Mountains. In this way, the unspecified temperature differences on the shore and the ups and downs in the temperature values become evident in the interior. Incidents of frost increase and they are carried over into the spring. The speed of the winds is 2 or 3 times higher at the stations on the shore. Together with the moisture values in the atmosphere, inconsistency occurs in the cloudiness levels. Precipitation values are halved as they are unable to overcome the mountain barrier. While the Küre Mountains incorporate the coastal zone into the Black Sea climate zone, it brings the interior regions closer to the continental climate regions. The low values of winter temperatures and the increase in summer precipitation of the inland stations reflect the similarity to the Northeast Anatolian climate. In the present study prepared as an example of the effect of geographical barriers between the coastal and the interior parts on the regional climate, the coastal stations of (the districts of) Inebolu and Cide were compared with that of Kastamonu in the interior part. Initially, the general geographical features of the region were discussed and then, comparatively, climate elements were mentioned respectively. 
Extended Abstract Introduction

The Western Black Sea Region has unique climatic conditions due to its geographical location, landforms and neighboring to the Black Sea. The mountains rising like a wall behind the coastline and the valleys opening onto these mountains play a significant part in the penetration of the sea effect into the interior in different degrees. These landforms that meet the air masses transform and send them off southward. The study area covers the area starting from the northern skirts of the Ilgaz Mountains and reaching the coastline by comprising a significant part of the Küre Mountains.

\section{Data and method}

In the present study prepared as an example of the effect of geographical barriers between the coastal and the interior parts on the regional climate, the coastal stations of (the districts of) Inebolu and Cide were compared with that of Kastamonu in the interior part. The basis of the study is composed of the data of the meteorological stations in the region regarding the climatic elements such as temperature, precipitation and wind. In places where there are no stations, these deficiencies have been tried to be removed by the way of interpolation depending on the elevation.

The northern regions of our country, compared to the south, receive the sun's rays at slightly more oblique angles. In the Kastamonu province, a difference of $1^{\circ} 12$ 'occurs between the falling angles of the rays at the beginning of the seasons. The average annual insolation time in the provincial center is more than the coastal stations with 5 hours 76 minutes. The reason for this is continentality and latitude. When the Johansson formula is applied to the region in order to determine the degree of continentality, the Kastamonu province has a higher terrestrial value compared to the districts in the coastal area and is close to the value of the interior parts of Anatolia.

The annual average temperatures at the stations in the study area are $13,7^{\circ} \mathrm{C}$ in Cide, $13,3^{\circ} \mathrm{C}$ in Inebolu, and $9,8^{\circ} \mathrm{C}$ in the provincial center. The annual average temperature difference, on the other hand, varies between $3,5^{\circ} \mathrm{C}$ and $3,9^{\circ} \mathrm{C}$. According to their temperature characteristics, The Kastamonu province is in the "Middle Zone Thermal Regime" type, while Cide and Inebolu stations are closer to the "Oceanic Character Regime" type. The amplitude value is higher in Kastamonu $\left(19.2^{\circ}\right)$ in comparison to Cide $\left(16.8^{\circ}\right)$ and İnebolu $\left(16.1^{\circ}\right)$. The adjustment of the Küre Mountains for the passage of air masses prevents the temperature rise in the interior zones in winter. The temperature values in parts of these mountains up to a significant height are above $0^{\circ}$. In the interior zones, it always has negative value in most places. The temperatures at the coastal stations drop below $0^{\circ}$ ten from November, and from May, no frost days are observed. Frost days in the Kastamonu province starting from October continue until the end of May.

The fact that wind speeds in Inebolu and Cide are higher than Kastamonu is due to the fact that there is no topographic obstacle that minimizes the wind speed. Relative humidity is over $70 \%$ in almost all months at coastal stations. There is a harmony between the high relative humidity in the autumn season and the increase in precipitation, and it is similar to the humidity rates in the Black Sea climate. The relative humidity of the Kastamonu province increases in winter months and these features are more reminiscent of the continental climate. The amount of precipitation which is $968.1 \mathrm{~mm}$ in Cide is $1017.5 \mathrm{~mm}$ in Inebolu and $480.2 \mathrm{~mm}$ in Kastamonu. These values increase even further due to the rise in height and roughness. The main reason for the different distribution of precipitation is the distance to the sea and the landforms. The number of days with snow increases as the altitude increases and as one goes from the coastline towards the interior parts, at the same time, the duration of snow that stay on the ground increases.

In Cide and Inebolu, according to Thorthwaite, in a humid, mesothermal, water-deficient summer season and a moderate climate close to the sea effect is observed. According to Köppen, both stations are in the mid-zone climates. According to De Martonne, on the other hand, both stations stay in the humid climate zone. In the Erinç classification, they are in the sub humid climate zone. On the contrary, according to Thornthwaite, Kastamonu falls into a type of sea-influenced climate with less humidity, moderate temperature, and little excess water. According to Köppen, they are in the middle zone, according to De Martonne, in the humid zone and according to Erinç in the semi-arid climate zone.

\section{Results and discussion}

Despite the fact that the different areas of the Kastamonu province are completely located within the Black Sea Region, there occur some significant differences in terms of climate characteristics. The global conditions only reveal the climate zone in which the region is located. The main reason, however, for the change within itself is the existence of the Black Sea and the characteristics of the Küre Mountains. While these mountains integrate the coastal parts into the Black Sea climate zone, they bring the interior regions closer to the continental climate zones. The temperature differences and fluctuations in temperature values that are not obvious on the coast become evident in the interior regions. Frost incidences increase and continue onto the spring months. The speed of the winds is 2-3 times higher at the stations on the coastline. Precipitation values are reduced by half as they cannot overcome the mountain barrier. The low values of winter temperatures and the increase in summer precipitation of the inland stations reflect the similarity to the Northeast Anatolian climate. All these are the unexpected changes in the climatic characteristics of the inner plateaus and basins in the short distance, which are not far from the coastline.

\section{Giriş}

Bat Karadeniz Bölümü; coğrafi konumu, yeryüzü şekilleri ve Karadeniz'e komşu oluşuyla kendine özgü iklim şartlarına sahiptir. Kıyı gerisinde bir duvar gibi yükselen dağlar ve bu dağlar üzerinde açılan vadiler, deniz etkisinin iç kısımlara farklı derecelerden sokulmasında önemli bir rol üstlenir. Kıyı kesiminden iç bükey bir uzanışla iç kısımların bağlantısını kesen bu dağlar, Küre Dağları olarak bilinir. Dağların gerisinde yer alan platoluk saha, İç Anadolu Bölgesinden yine paralel bir dağ sırası olan Ilgaz Dağları ile ayrılır. İnceleme alanı, Ilgaz Dağları'nın kuzey eteklerinden başlayan ve Küre Dağları'nın önemli bir kısmını içine alarak kıyıya ulaşan alanı kapsar (Şekil 1). 


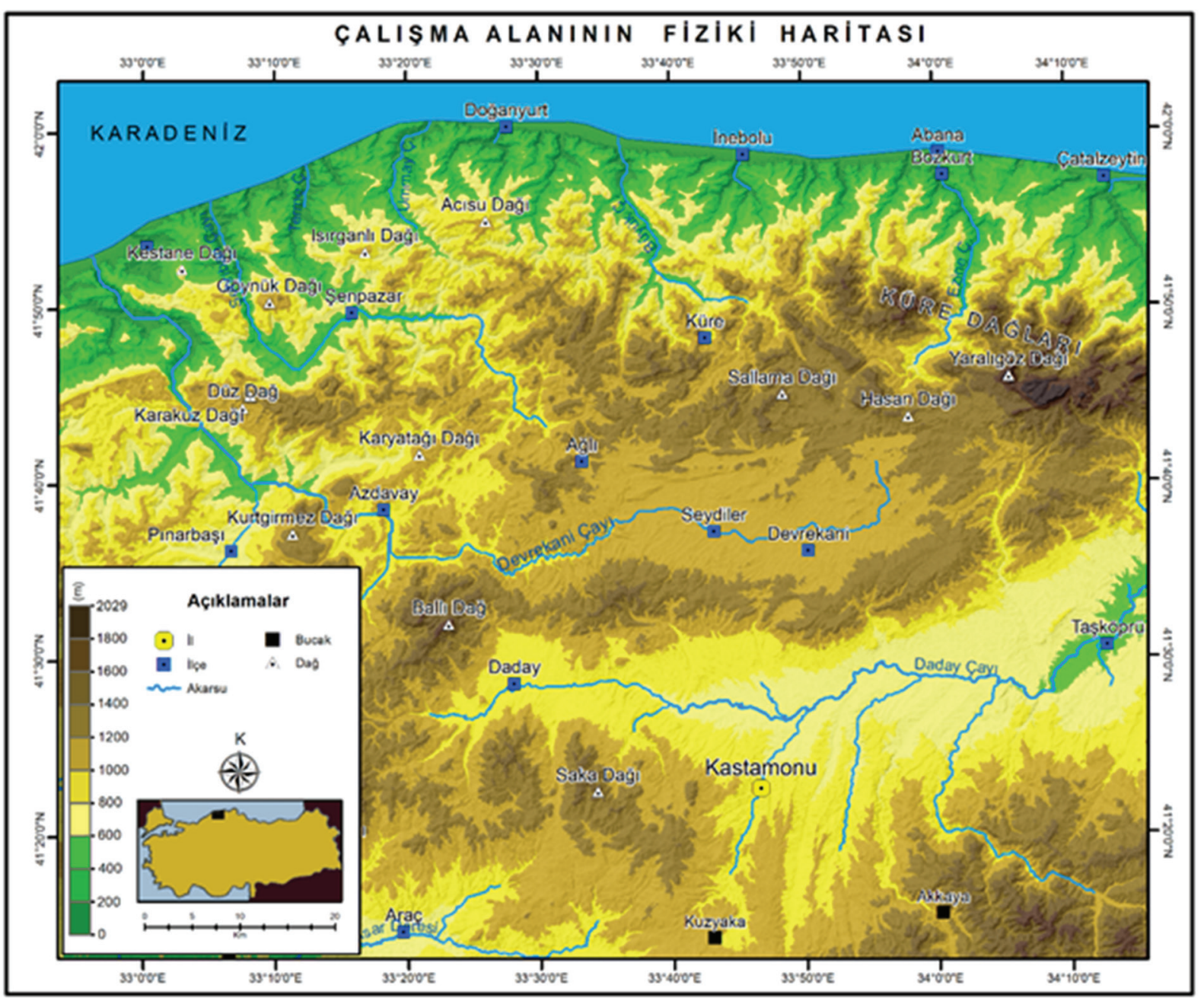

Şekil 1. Küre Dağları ve yakın çevresinin lokasyon ve topografya haritası.

Figure 1. Location and topography map of Kure Mountains and its surrounding

Karadeniz kıyılarından itibaren ilk sırayı teşkil eden kütle olan Küre Dağlarının, en yüksek noktası 2000 metrenin üzerine çıkar (Yaralıgöz Tepesi 2019 m), Bartın-Sinop arasında doğu-bat yöndeki uzunluğu ise 300 km'yi geçer. Kuzeyden gelen hava kütlelerinin karşılaştı̆̆ ilk engebe olması dolayısıyla, kıyı ile iç kısımlar arasında önemli iklim farklılıklarının ortaya çıkmasına yol açar. Hemen güneyinde yer alan, çoğu yerde yüksekliği 1000 metreyi bulan plato ve depresyonlarda karasal etkilerin artması bu durumla ilgilidir. İç Anadolu ile ikinci bir engel oluşturan Ilgaz Dağları (Büyükhacat Tepesi 2587 m) da kısa mesafede bu etkiyi kuvvetlendirir. Birbirine yakın ve önemli yükseltilere sahip bu iki dağ sırası arasına sokulmuş vadiler, daha çok doğu bat yönünde uzanır. Kimi yerde, kütleleri yararak kuzeye yönelen vadilerin, yamaçları çok dik ve derin kanyonlar halindedir. Hava kütlerini farklı şekilde karşılayan bu yer şekilleri, adeta bir dönüşüme uğratarak, güneye doğru gönderir.

Orta kuşağın tropikal bölgeye daha yakın bir konumunda olan Türkiye, hava kütlelerinin oluşumu açısından bir kaynak bölgesinde yer almaz. Ancak kutupsal ve tropikal hava kütlelerinin karşılaşma alanı olmasıyla, yıl içinde oldukça farklı hava şartlarının ortaya çıktı̆̆ı geçiş sahası konumundadır. Ülkenin kuzeyi, dolayısıyla Karadeniz Bölgesi daha çok kutupsal hava kütlelerinin, deniz üzerinden geçerken aldığı nemle yıl boyunca hem yağışlı hem de serin bir özellik gösterir.

\section{Veri ve Yöntem}

Kıyı ile iç kısımlar arasında yer alan coğrafi engellerin, bölge iklimine etkisine bir örnek olarak hazırlanan bu çalışmada; kıyı istasyonlarından İnebolu ve Cide, iç kısımda yer alan Kastamonu istasyonu ile karşılaştırılmıştır. Bölge ile ilgili yapılan en kapsamlı iklim çalışması Kurter tarafindan hazırlanarak, "Kastamonu ve Çevresinin İklimi" adıyla 1971'de yayımlanmıştır. $\mathrm{Bu}$ çalışmada rasatlar sınırlı olmasına rağmen Kurter, iklimi oluşturan elemanlara etraflıca yer vermiştir. Ancak, sadece karşılaştırma istasyonlarının rasatları dikkate alındığından, yeterince kesin sonuçlara ulaşılamamıştır. Yöredeki iklimin kontrol ettiği su kaynaklarının etkinliği, başta tarım ve hayvancılık olmak üzere birçok ekonomik faaliyet açısından önemlidir. Bu sebeple rasat istasyonların yoğunluğunun çok fazla olduğu günümüzde bu tür çalışmaların sayıca artması, yöre ikliminin ortaya çıkarılması ve bu tür faaliyetlerin yürütülmesi için büyük önem taşımaktadır.

Çalışmanın temelini; bölgede bulunan meteoroloji istasyonlarının sıcaklık, yağış ve rüzgar gibi iklim elemanlarına ilişkin verileri oluşturmaktadır (M.G.M., 2016). Alınan bu veriler coğrafi metoda sadık kalınarak işlenip, yorumlanarak harita, tablo, grafikler eşliğinde sunulmuştur. Sıcaklık ve yağış haritalarının hazırlanmasında istasyonların verileri esas alınmış, ancak istasyon olmayan yerlerde, yükseltiye bağlı olarak enterpolasyon yoluyla bu eksikler giderilmeye çalışılmıştır. Sayısal veriler ArcGIS 10.8 programı kullanılarak düzlem üzerine aktarılmıştır. Bu şartlar 
altında oluşan çalışmada ilk olarak bölgeyi ilgilendiren genel coğrafi özellikler ele alınmış, daha sonra karşılaştırmalı olarak sırasıyla iklim elemanları ve iklim tiplerinden bahsedilmiştir.

\section{Bulgular ve Tartş̧ma}

\section{1. İklimi Etkileyen Fiziki Faktörler}

İklim, doğal görünümü oluşturan her bir eleman üzerine, ayrı ayrı ve geniş ölçüde etki yapar. Yeryüzü şekilleri, bitki örtüsünün yapısı, dağılışı ve onu meydana getiren türler, toprak tipleri, yeralt ve yer üstü suları iklimle sıkı sıkıya ilişkilidirler (Kurter, 1982). Buna bağlı olarak iklim değiştikçe doğal bölgeler de değişmektedir. Yeryüzünün çeşitli kesimlerinde farklı iklim şartlarının ortaya çıkmasında rol oynayan bir kısım faktörler vardır. Bunlardan birincisi, Ülkenin konumunu ve genel atmosfer dolaşımını ilgilendiren küresel faktörler, ikincisi ise bölgenin coğrafi özelliklerine bağlı olarak meydana gelen termik ve dinamik faktörlerdir.

\subsubsection{Küresel faktörler}

Bu gruba giren etkenler, Türkiye'de mevsimlik hava tiplerini ve dolayısıyla mevsimlerin genel karakterini ana çizgileriyle belirler. Türkiye $36^{\circ}-42^{\circ}$ kuzey paralelleri arasında yer alan bir kara parçasıdır ve genel olarak tropikal kuşakta, kıtaların batı tarafinda gerçekleşen, Akdeniz iklim tipi olarak tanınan bir makroklima sahası içinde ve onu meydana getiren faktörlerin etkisi altında bulunur (Erinç, 1984).

Türkiye'yi etkisi altnnda bulunduran iki esas hava kütlesi (kutbi, tropikal) bazı alt tiplere ayrılır. Kutupsal hava kütlelerini, denizel özellikteki maritim polar (mP) ve karasal özellikteki kontinental polar (cP) oluşturur. Tropikal hava kütlelerini ise maritim tropikal (mT) ve kontinental tropikal (cT) hava kütleleri temsil eder. Sahaya sokulan hava kütleleri aslında yalnızca kutbi ve tropikal terimleriyle ifade edilemeyecek kadar çok çeşitlidir. Bu hava kütlelerinin ortaya çıktıkları mevsimler ve etki dereceleri de oldukça farklıdır.

Kış mevsimi hava kütlelerinin hareketi açısından daha aktif bir dönemdir. Kutup bölgelerinden gelen gezici alçak basınçlar sıcaklıkların düşmesine ve yağışlara sebep olur. Bu hava kütlelerinin önünde yer alan soğuk cepheler Karadeniz'i aşarken nemle yüklenerek kıyı ve gerisindeki dağlar üzerinde etkili olur. Atlas Okyanusunun kuzeyinde oluşan denizel kökenli hava kütleleri, önce Avrupa üzerinde kararlı hale gelir, daha sonra nemle yüklenerek bölgeye ulaşır. Akdeniz üzerinden gelen yine aynı tip hava kütleleri, meydana getirdikleri soğuk cephelere bağı ı olarak, Karadeniz kıyılarına yağış bırakır. Sibirya yüksek basıncına ait karasal karakterdeki hava kütleleri ise Rusya platolarını geçtikten sonra, gerek Karadeniz gerekse Hazar havzasından nem kazanarak kuzey kıyılarda etkili olur.

Yaz mevsiminde kutupsal hava kütleleri kuzeye çekilirken, tropikal hava kütleleri alanlarını genişleterek sıcaklıkların artmasını sağlar. Asor yüksek basınç alanının doğuya doğru genişlemesi kış mevsimine nazaran hava hareketlerinde daha sade bir görünüme yol açar. Deniz üzerinden geçip kıyıdaki dağlarda yükselerek kümülüs bulutlarını oluşturur. Basra alçak basıncına bağlı olarak meydana gelen karasal hava kütleleri ise güney ve güneydoğudan ilerleyerek kurutucu bir etki yapar. Yine bu mevsimde kısmen kutupsal hava kütlelerinin etkisi görülebilir. Kuzeye çekilmiş olan soğuk cephe alanını genişleterek incele- me alanı boyunca cephesel yağışlara meydan verir. Karasal nitelikli olan antisiklonlar nadiren güneye iner fakat yağış bırakır.

Yerin biçimi, yeryüzünün her noktasının aynı değerde ışın ve enerji almasına engel olan bir etmendir. Uzaydan birbirine paralel demetler halinde gelen güneş ışınları, yuvarlak olan yerkürenin Ekvator bölümüne dik, kutup bölgelerine yatık açılarla düşer (Erol, 1999). Türkiye, konumu dolayısıyla bu ışınları hiçbir zaman dik açılarla alamaz. Ancak bazı yerler, yeryüzü şekillerinin eğimi sebebiyle ışınları dik karşılayabilir. Ülkemizin kuzey bölgeleri, güneye göre ışınları biraz daha eğik açılarla alır. Karadeniz Bölgesinin kıyıya komşu alanları iç kısımlara nazaran enlemle tezat oluşturacak şekilde daha ılımandır. Bu sebeple en güneyinden $40^{\circ} 49^{\prime}$ kuzey, en kuzeyinden ise $42^{\circ} 01^{\prime}$ kuzey enlemi geçen Kastamonu'da, bu durum zaten sıcaklık farkını kapatacak ölçüde değildir. Mevsimlerin başlangıç tarihleri olan ekinoks ve solstis tarihlerinde ışınların düşme açıları arasında $1^{\circ} 12^{\prime}$ fark ortaya çıkmaktadır (Şekil 2). Güneş ışınlarının ekvatora dik geldiği tarihler olan 21 Mart - 23 Eylül tarihlerinde, ışınlar en kuzeyde yer alan enlemlere $47^{\circ} 59^{\prime}$, en güneydeki enlemlere ise $49^{\circ} 11^{\prime}$ açıyla gelmektedir. Yengeç dönencesine dik geldiği tarih olan 21 Haziran'da bu değer; kuzeyde $72^{\circ} 38^{\prime}$, güneyde $71^{\circ} 26^{\prime}$ şeklindedir. En eğik geldiği 21 Aralık tarihinde ise kuzeye $24^{\circ} 32^{\prime}$, güneye $25^{\circ} 44$ açıyla düşmektedir. Bu durum kıyı ile iç kısımlar arasında yıllık güneşlenme süresine de yansımaktadır.

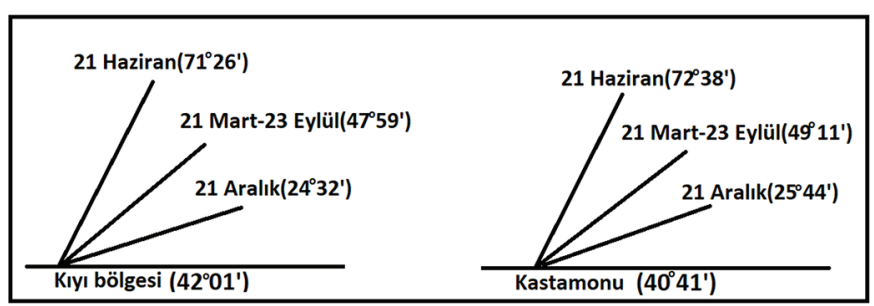

Şekil 2. Kastamonu ilinin en kuzey ve en güney noktasında güneşin ufuk düzlemi ile yaptığı açılar.

Figure 2. The angles of the solar radiation at the northern and southern boundaries of Kastamonu province.

Kastamonu'da 2 saat 23 dakika ile en düşük güneşlenme süresi ocak ayındadır. İnebolu'da 2 saat 15 dakika, Cide'de 1 saat 42 dakika ile en düşük güneşlenme süresi aralık ayıdır. Güneşlenme süresinin en uzun olduğu ay ise tüm istasyonlarda temmuz ayı olarak dikkati çekmektedir. Temmuz ayında en uzun güneşlenme süresi 10 saat 34 dakika ile Cide istasyonuna aittir. Yaz dönemindeki güneşlenme, yıllık ortalama güneşlenme süresinin aksine kıyı istasyonlarında daha fazladır. Yıllık ortalama güneşlenme süreleri incelendiğinde, 5 saat 76 dakika ile Kastamonu ilk sıradadır. İnebolu'da bu süre 5 saat 44 dakikadır. Kastamonu'da güneşlenme süresinin kıyı istasyonlarına göre fazla olmasının temel sebebi enlem ve karasal etkidir. Cide ve İnebolu'da ise denizel etkilerle beraber bulutluluğun yüksek olması, bu sonucu ortaya çıkarır (Tablo 1, Şekil 3).

Anlaşılacağı üzere küresel şartlar, iklim konusunda birinci derecede belirleyici rol oynar. Inceleme alanında sıcaklıkların seyri, en başta güneş ışınlarının geliş açılarında yıl boyunca meydana gelen büyük değişiklikle ilgilidir. Mevsimlerin oluşumu ve mevsim özelliklerini ortaya çıkması, bu duruma bağlı olarak gerçekleşir. Yine bölgenin her mevsim yağışlara maruz kalması da her ne kadar dağların uzanışı ve kuzeyinde bir denizin yer almasıyla ilgili olsa da kutupsal kökeni hava kütlelerinin 
Tablo 1. Cide, İnebolu ve Kastamonu’nun aylık ve yıllık güneşlenme süreleri.

Table 1. Monthly and Annual solar radiation periods according to Cide, Inebolu and Kastamonu weather stations.

\begin{tabular}{|c|c|c|c|c|c|c|c|c|c|c|c|c|c|}
\hline İstasyon & 0 & Ş & $\mathbf{M}$ & $\mathbf{N}$ & M & $\mathbf{H}$ & $T$ & A & E & E & $\mathbf{K}$ & A & Yillık \\
\hline Cide & 1,51 & 3,12 & 4,25 & 5,53 & 7,44 & 9,36 & 10,34 & 9,50 & 7,15 & 5,10 & 3,25 & 1,42 & 5,66 \\
\hline İnebolu & 2,23 & 2,52 & 3,46 & 5,00 & 6,53 & 9,26 & 10,12 & 9,12 & 7,06 & 4,51 & 3,30 & 2,15 & 5,44 \\
\hline Kastamonu & 2,21 & 3,34 & 4,40 & 5,43 & 7,25 & 8,43 & 10,01 & 9,32 & 7,32 & 5,34 & 3,48 & 2,58 & 5,76 \\
\hline
\end{tabular}

genişlemesi ve hareket istikametleriyle de yakından ilgilidir. İnceleme alanı, kuzeye dönük bir konumda olduğu için güneyden ziyade kuzeyden gelen hava kütleleri daha baskındır. Lokal şartlar ise, Orta kuşağın diğer bölgelerinde olduğu gibi, bu bölgenin ayırt edici özelliklerini ortaya çıkararak kendi iklim karakterinin oluşumunda önemli rol oynamaktadır.

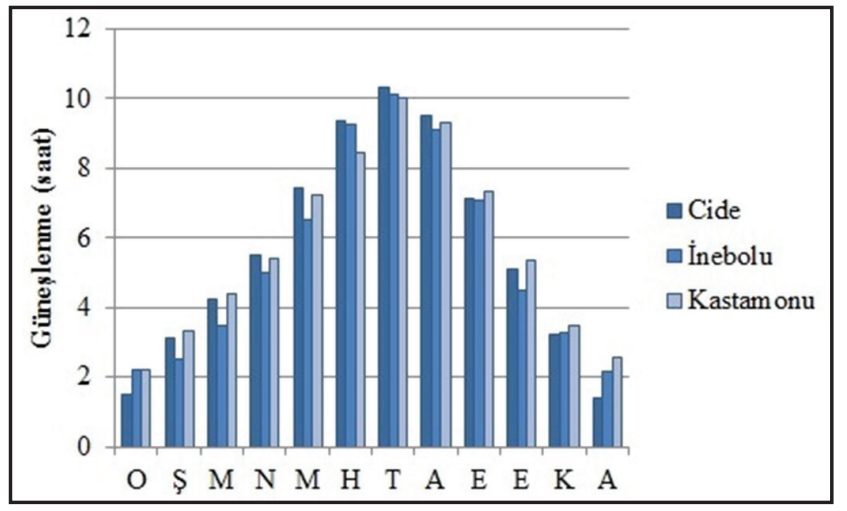

Şekil 3. İnceleme alanında güneşlenme süresinin aylara göre değişimi. Figure 3. Distribution of the solar radiation period by the months in the study area.

\subsubsection{Bölgesel faktörler}

Bir yerin iklim şartlarının belirlenmesinde yalnızca küresel faktörler değil, bunların yanında bazı coğrafi faktörler de etkilidir. Bu gibi faktörlerden kara ve denizlerin dağılışı, deniz akıntıları, büyük röliyef hatları gibileri daha ziyade atmosferin genel sirkülasyonu üzerinde etkilerini gösterirler (Kurter, 1971). Bat Karadeniz bölümünde mevcut şartların oluşması özellikle yer şekilleri ve kara-deniz dağılımı gibi coğrafi faktörleri ön plana çıkarır.

Karasallık derecesi bakımından, inceleme sahasının hemen kuzeyinde Karadeniz'in bulunması, sahanın iklim şartları üzerinde etkili olmuştur. Sahadaki istasyonların sıcaklık değerleri ve coğrafi enlemi kullanılarak, Johansson formülü kıyı ve iç kısımlara uygulandığında, Kastamonu merkezinin bulunduğu kısımlarda karasallık derecesi \%36 çıkarken, Karadeniz kıyılarında bu değer \%20'dir. Bu duruma göre Kastamonu'nun iç kesimdeki ilçeler, kıyı kesimdeki ilçelere göre daha yüksek karasallık değerine sahiptir ve Anadolu'nun daha iç kesimlerinin değerine yakınlık göstermektedir. Küre dağlarının kıyıya paralel uzanması, iç kısımlardaki karasallığı daha kısa mesafede arttırmıştır.

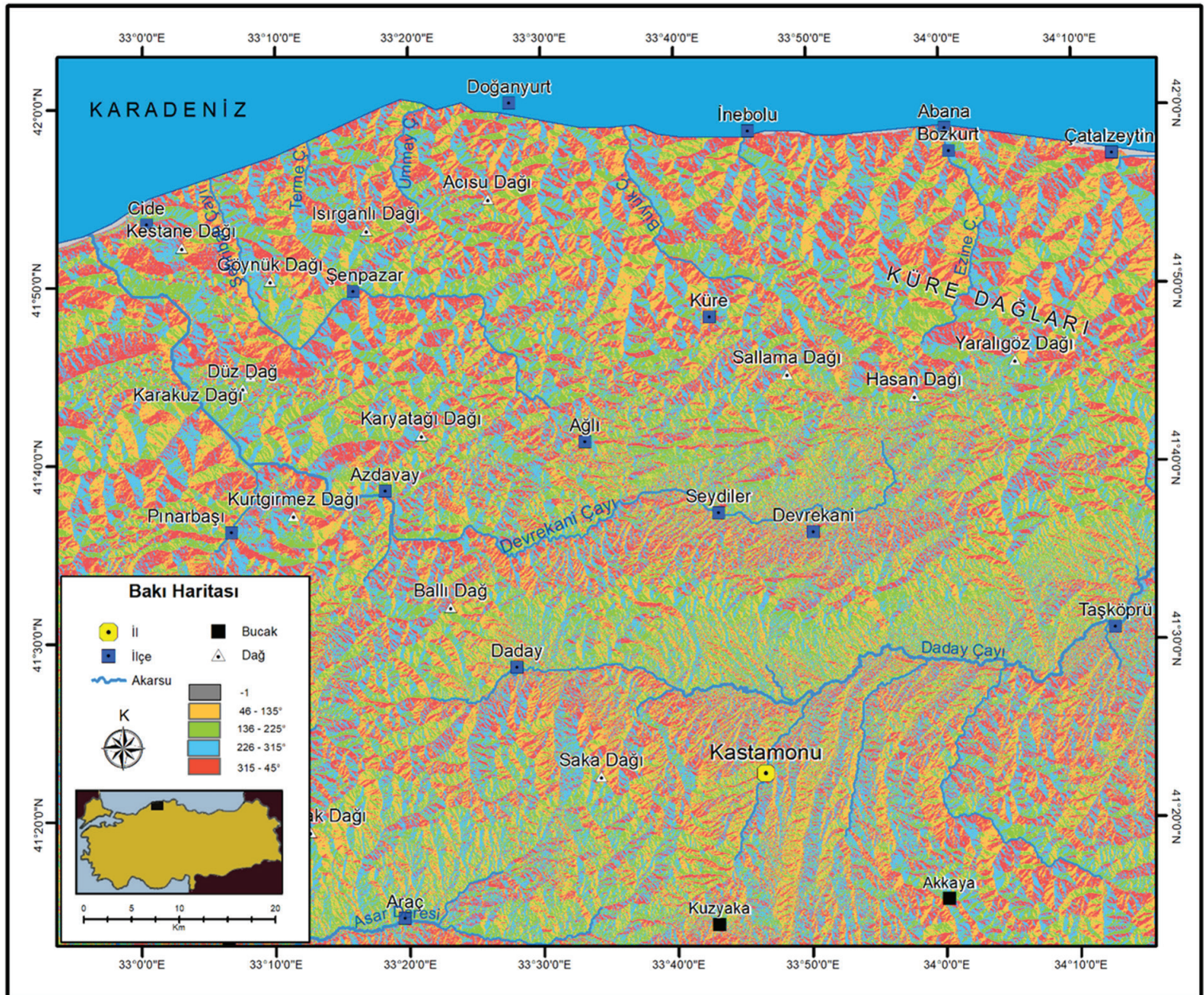

Şekil 4. Küre Dağları ve yakın çevresinin bakı haritası.

Figure 4. Aspect map of Küre Mountains and its surrounding. 
Orografik açıdan ise, kıyıya paralel uzanmakta olan Küre Dağları, deniz ile iç kısımlar arasında bir engel teşkil eder. En yüksek noktaları hemen hemen 2000 m'ye ulaşan bu dağ sistemi ortalama 1500 m'lik yükseltiler halinde Kastamonu ve çevresini Karadeniz'den ayırır. Yıllık yağış toplamı açısından, kıyıdan iç kesimlere doğru, bu durum iyice belirginleşir. Gerçekten Kastamonu, İnebolu'nun hemen hemen yarısından daha az yağış almaktadır. Yani kıyıda bol olan yağışlar bu orografik engelin kuzey yamaçları üzerinde, gerek Karadeniz'i aşan hava kütlelerinin gerekse Karadeniz'i kat eden depresyonların bıraktıkları yağışlar olup, iç kısımlar bundan kısmen mahrum kalmaktadır. Ancak, 2000 m'ye yaklaşan yüksek arızalı sahalar deniz etkisini tam anlamıyla engelleyemezler. Küre dağlarının gedikleri ve bilhassa batıdan nüfuz eden hava kütleleri buralara sokulurlar ve yüksek yerlere daha fazla yağış bırakabilirler (Şekil 4). Kastamonu'nun kuzey ve güneyden yüksek kütlelerle sınırlanmış oluşu, Karadeniz ve güneydeki İç Anadolu hava şartlarının, buraya nüfuzunu frenleyebilmektedir (Kurter, 1971).

\section{2. İklim Elemanları}

İklim; coğrafi ortamın şekillenmesinden, insan ve bitki yaşamına kadar birçok konuyu yakından etkileyen bir faktördür. İklimin bu etkileri iklim elemanları (sıcaklık, yağış, rüzgar vb.) sayesinde gerçekleşir (Tuğ, 2006).

\subsubsection{Sıcaklık şartları}

Coğrafi koşulları ve yaşam etkinliklerini ve diğer iklim elemanlarını en yakından kontrol eden iklim öğesi atmosferin sıcaklığıdır (Erol,1999). Sıcaklık bütün bitkilerin hayati faaliyetleri için gerekli olan bir iklim elemanıdır. Bu nedenle bitkilerin çimlenmesi, büyümeleri ve çoğalmaları sıcaklıkla doğrudan ilişkilidir (Dönmez, 1985).

Inceleme alanındaki istasyonlarda yıllık ortalama sıcaklıklar Cide'de $13,7{ }^{\circ} \mathrm{C}$, İnebolu'da $13,3{ }^{\circ} \mathrm{C}$, Kastamonu'da 9,8 ${ }^{\circ} \mathrm{C}$ 'dir. Bu değerlere göre örnek alınan ilçelerde yıllık ortalama sıcaklık farkı $3,5^{\circ} \mathrm{C}$ ile $3,9^{\circ} \mathrm{C}$ arasında değişmektedir. Sıcaklık değerleri aylar bazında incelendiğinde ise şu sonuçlara ulaşılmaktadır: ocak ve şubat ayları istasyonlardaki ortalama sıcaklığın en düşük olduğu aylardır. Kastamonu'da $\left(-1,1^{\circ} \mathrm{C}\right)$ ortalama sıcaklığın en düşük değeri ocak, Cide $\left(5,8^{\circ} \mathrm{C}\right)$ ve İnebolu $\left(5,9^{\circ} \mathrm{C}\right)$ da ise şubat ayı olarak görülmektedir. Ortalama sıcaklıkların en yüksek olduğu aylar ise temmuz ve ağustos aylarıdır. Kastamonu $20,3^{\circ} \mathrm{C}$ ile ortalama sıcaklığın en yüksek olduğu ay temmuzdur. İnebolu'da en sıcak aylar $22,0^{\circ} \mathrm{C}$ ile temmuz ve ağustos olarak görülmektedir. Cide'de diğer kıyı istasyonundan farklı olarak ortalama sıcaklığın en yüksek olduğu ay $22,4^{\circ} \mathrm{C}$ ile tek başına ağustostur (Tablo 2, Şekil 5). En sıcak ve en soğuk ayların bir ay gecikmeli olarak gerçekleşmesi, Cide ve İnebolu'nun denize açık olmasıyla ilgilidir.
Kastamonu'da ortalama sıcaklıkların yılın 10 ayı $20{ }^{\circ} \mathrm{C}$ 'nin altında olduğu görülmektedir. Bunun neticesinde Kastamonu "Orta Kuşak Termik Rejim" tipine girmektedir. Cide ve İnebolu istasyonlarında ortalama sıcaklıklar hiçbir ayda $0{ }^{\circ} \mathrm{C}$ 'nin altına düşmemektedir. Bu durumda, istasyonların "Oseanik Karakterli Rejim" olarak adlandırılması uygun olacaktır (Coşkun \& Akbaş, 2017).

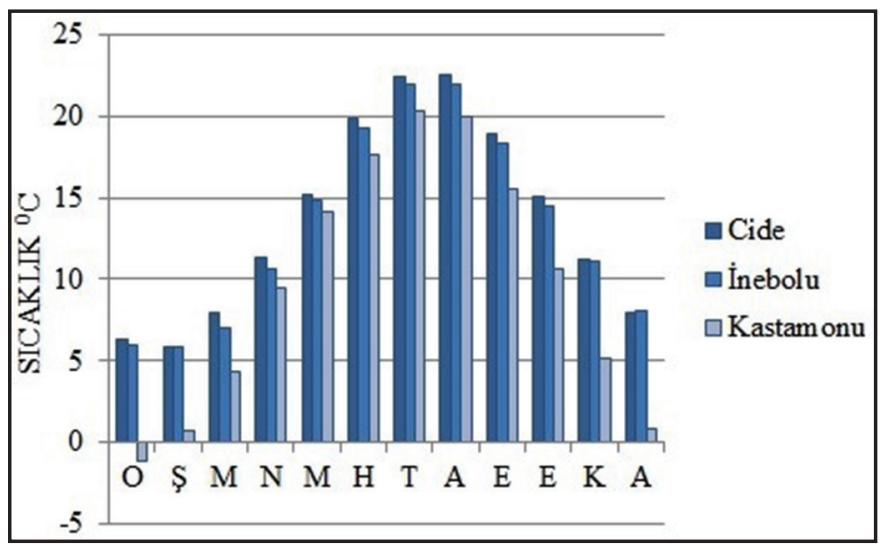

Şekil 5. İnceleme sahasındaki istasyonların ortalama sıcaklıkların aylara dağılımı.

Figure 5. Distribution of the mean temperature by months of the weather stations in the study area.

En sıcak ay ile en soğuk ay arasındaki ortalama sıcaklık farkı, karasallık/denizellik ilişkisini belirlemeyi kolaylaştırır. Bu farkın en yüksek olduğu istasyonlarda karasallığın, farkın en az olduğu istasyonlarda ise denizelliğin egemen olduğu söylenebilir (Duran, 2017). Yıl içerisinde en sıcak ayın ortalaması ile en soğuk ayın ortalaması arasındaki sıcaklık farkı olan amplitüd değerleri incelendiğinde, Karadeniz'e yakın istasyonlarda bu değerin düşük, iç kesimlerdeki istasyonlarda ise fazla olduğu görülmektedir. Amplitüd değeri Cide $\left(16,8^{\circ} \mathrm{C}\right)$ ve İnebolu' ya $\left(16,1{ }^{\circ} \mathrm{C}\right)$ nazaran Kastamonu'da $\left(19,2{ }^{\circ} \mathrm{C}\right)$ yüksektir. Kıyı istasyonlarında en soğuk ve en sıcak ayların, sırasıyla şubat ve ağustosa denk gelmesi ve yıllık sıcaklık farklarının daha az olması tipik Karadeniz ikliminin etkisinden dolayıdır.

Inceleme sahasındaki istasyonların minimum sıcaklık değerleri incelendiğinde, deniz etkisinden uzak iç kesimdeki Kastamonu'da eylül ve ekim ayında değerler $0^{\circ} \mathrm{C}^{\prime}$ nin altnna inmektedir. Kasım ayından itibaren tüm istasyonlarda sıcaklık $0^{\circ} \mathrm{C}^{\prime}$ nin altındadır. Yani; aralık, ocak, şubat, mart ve nisan aylarında minimum sıcaklılar istasyonların tamamında $0{ }^{\circ} \mathrm{C}^{\prime}$ nin altındadır. Mayıs ayında İnebolu istasyonu dışındaki tüm istasyonların sıcaklığı $0{ }^{\circ} \mathrm{C}$ 'nin altındadır (Tablo 3). Kastamonu istasyonunda en düşük sıcaklık değerinin diğer istasyonlardan bir ay önceye rastlamasının nedeni, karasallık derecesinin yüksek olması ve deniz etkisinin iç kesimlere sokulamamasıdır. Deniz etkisinde olan yerlerde atmosferin nem derecesi daha fazla olduğundan sıcaklıklar daha yüksek seyretmektedir.

Tablo 2. Cide, İnebolu ve Kastamonu'da ortalama sıcaklıkların aylara dağılımı $\left({ }^{\circ} \mathrm{C}\right)$.

Table 2. Distribution of the mean temperature by the months at Cide, Inebolu and Kastamonu weather stations ( $\left.{ }^{\circ} \mathrm{C}\right)$.

\begin{tabular}{lcccccccccccccccc}
\hline İstasyon & $\mathbf{O}$ & $\mathbf{S}$ & $\mathbf{M}$ & $\mathbf{N}$ & $\mathbf{M}$ & $\mathbf{H}$ & $\mathbf{T}$ & $\mathbf{A}$ & $\mathbf{E}$ & $\mathbf{E}$ & $\mathbf{K}$ & $\mathbf{A}$ & Yıllık \\
\hline Cide & 6,3 & 5,8 & 7,9 & 11,4 & 15,2 & 19,9 & 22,4 & 22,6 & 18,9 & 15,1 & 11,2 & 7,9 & 13,7 & \\
İnebolu & 6,0 & 5,9 & 7,0 & 10,6 & 14,8 & 19,3 & 22,0 & 22,0 & 18,3 & 14,5 & 11,1 & 8,1 & 13,3 \\
Kastamonu & $-1,1$ & 0,7 & 4,3 & 9,5 & 14,2 & 17,6 & 20,3 & 20,0 & 15,6 & 10,6 & 5,1 & 0,8 & 9,8 \\
\hline
\end{tabular}


Tablo 3. Cide, İnebolu ve Kastamonu'da minimum sıcaklıkların aylara dağılımı $\left({ }^{\circ} \mathrm{C}\right)$.

Table 3. Distribution of the minimum temperatures by the months at Cide, Inebolu and Kastamonu weather stations ( ${ }^{\circ} \mathrm{C}$ ).

\begin{tabular}{lccccccccccccccc}
\hline İstasyon & $\mathbf{O}$ & $\mathbf{S}$ & $\mathbf{M}$ & $\mathbf{N}$ & $\mathbf{M}$ & $\mathbf{H}$ & $\mathbf{T}$ & $\mathbf{A}$ & $\mathbf{E}$ & $\mathbf{E}$ & $\mathbf{K}$ & $\mathbf{A}$ & Yıllık \\
\hline Cide & $-7,9$ & $-10,4$ & $-7,6$ & $-1,8$ & $-1,6$ & 5,4 & 9,7 & 8,1 & 2,4 & 1,4 & $-2,2$ & -8 & $-10,4$ \\
İnebolu & $-8,5$ & -10 & $-7,7$ & $-1,82$ & 2 & 7,5 & 10,4 & 10,8 & 5 & 1,4 & -5 & $-5,8$ & $-10,0$ \\
Kastamonu & $-26,9$ & $-22,3$ & $-19,7$ & $-8,5$ & $-3,6$ & 0,2 & 3,8 & 0,9 & $-1,5$ & $-7,5$ & $-19,3$ & $-23,7$ & $-26,9$ \\
\hline
\end{tabular}

İstasyonların maksimum sıcaklıkları incelendiğinde, Kastamonu'da temmuz ve ağustos ayı sıcaklıklarının $40^{\circ} \mathrm{C}^{\prime}$ nin üzerine çıktı̆̆ı görülür. Diğer istasyonlarda sıcaklık bu derece yükselmez. Kış aylarında kıyı istasyonlarının sıcaklık değerleri Kastamonu'ya göre daha fazladır. İnebolu'da ocak ayında $24^{\circ} \mathrm{C}^{\prime}$ nin üzerine çıkan sıcaklık, Kastamonu'da $17,3^{\circ} \mathrm{C}^{\prime}$ dir. Bu değerler, Kastamonu çevresinde atmosferin, diğerlerine göre nem bakımından zayıf olduğuna işarettir (Tablo 4).
Ortalama sıcaklığın sahaya dağılımını daha iyi yansıtmak için hazırlanan sıcaklık haritaları incelendiğinde; yeryüzü şekilleri, deniz-kara etkisi net bir şekilde ortaya çıkar. Kış aylarını temsil etmek üzere yapılan ocak ayı izoterm haritasında (Şekil 6); kıyı istasyonları ve Küre Dağları'nın önemli bir yükseltisine kadar olan yerlerde sıcaklık değerleri $0^{\circ} \mathrm{C}^{\prime}$ nin üzerindedir. Dağların hava kütlelerini kestiği iç kısımlarda ise, çoğu yerde daima eksi değerlerdedir. İç bölgelerde yüksekten alçağa doğru kısmen sıcaklıklar sıfıra yaklaşır. Devrekani Çayı havzasında yer alan

Tablo 4. Cide, İnebolu ve Kastamonu'da maksimum sıcaklıkların aylara dağııımı $\left({ }^{\circ} \mathrm{C}\right)$.

Table 4. Distribution of the maximum temperatures by the months at Cide, Inebolu and Kastamonu weather stations $\left({ }^{\circ} \mathrm{C}\right)$.

\begin{tabular}{|c|c|c|c|c|c|c|c|c|c|c|c|c|c|}
\hline İstasyon & 0 & \$̧ & $\mathbf{M}$ & $\mathbf{N}$ & $\mathbf{M}$ & $\mathbf{H}$ & $\mathrm{T}$ & A & $E$ & $E$ & $\mathbf{K}$ & A & Yıllık \\
\hline Cide & 23,5 & 24,8 & 30,2 & 34,7 & 34,2 & 39,1 & 35,3 & 35,5 & 34,6 & 36,3 & 29,7 & 27,7 & 39,1 \\
\hline İnebolu & 24,4 & 28,4 & 30,2 & 34,3 & 35,7 & 39,7 & 35,2 & 35,8 & 31,8 & 34,4 & 30,2 & 28,4 & 39,7 \\
\hline Kastamonu & 17,3 & 21,1 & 27,8 & 31,4 & 35,1 & 37,5 & 42,2 & 40,2 & 36,5 & 32,5 & 24,7 & 21,1 & 42,2 \\
\hline
\end{tabular}

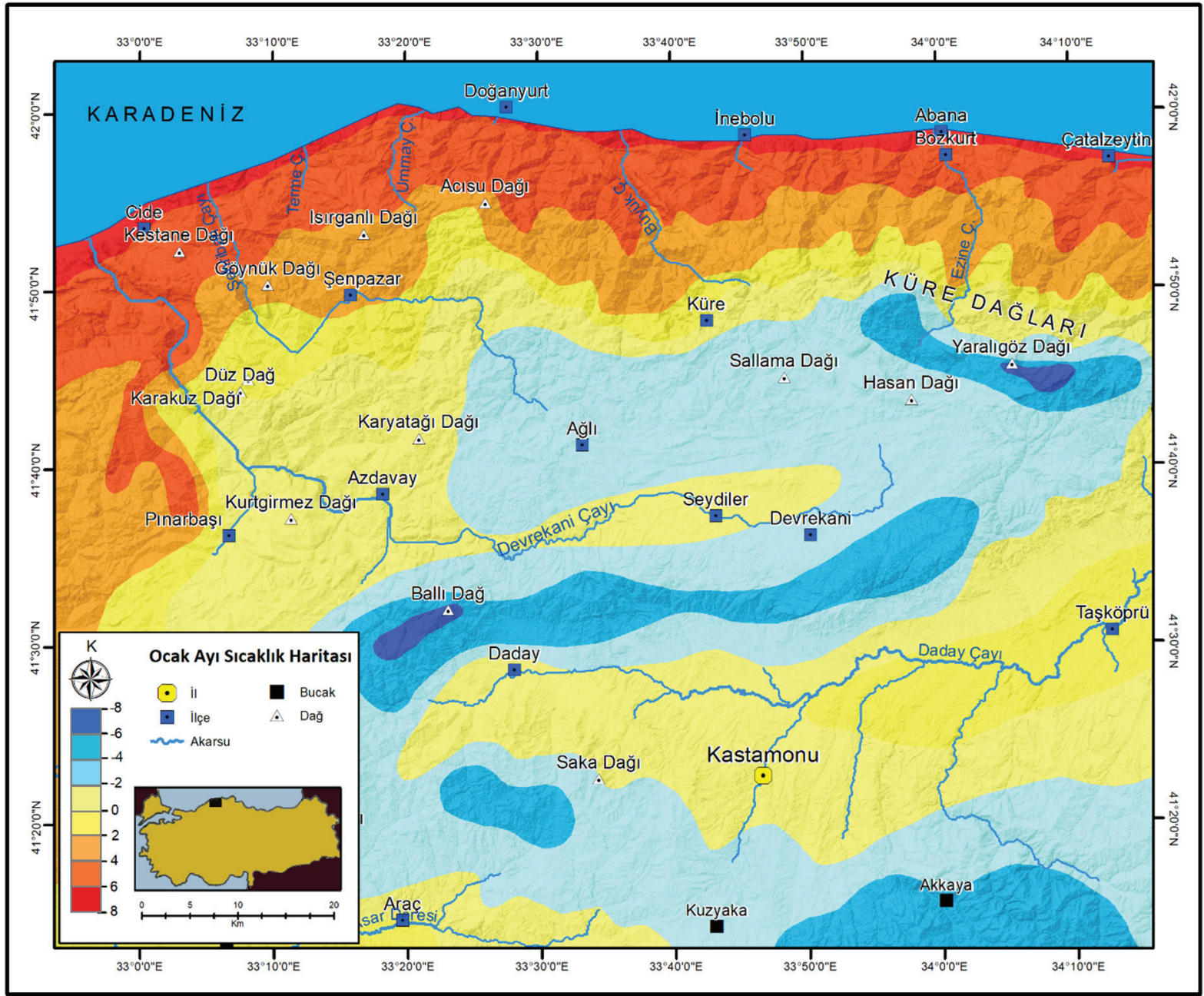

Şekil 6. İnceleme sahasının ocak ayı ortalama sıcaklıklarına göre hazırlanan izoterm haritası $\left({ }^{\circ} \mathrm{C}\right)$.

Figure 6. Isotherm map of the mean temperatures in January of the study area $\left({ }^{\circ} \mathrm{C}\right)$. 
Pınarbaşı'da $-1,6{ }^{\circ} \mathrm{C}$, Azdavay'da $-1,4{ }^{\circ} \mathrm{C}$, Devrekani'de ise -2 ${ }^{\circ} C^{\prime}$ ye kadar düşer. Kıyı kuşağı boyunca kurulan Cide, İnebolu, Doğanyurt ve Bozkurt yerleşmeleri, $6{ }^{\circ} \mathrm{C}$ izoterm eğrisi içerisinde kalır. Küre Dağları́nın kuzeyinde yükseldikçe hızla düşen sıcaklık ortalamaları, zirvede $-6{ }^{\circ} C^{\prime}$ nin altına kadar iner. Dağın güneyi boyunca alçaldıkça sıcaklıklarda önemli bir artış olmaz. Daha güneyde sıralanan Ballıdağ ve Ilgaz kütleleri sıcaklıkların en düşük olduğu yerleri teşkil eder. Soğuk mevsimde iç plato ve havzalarla dağlık kesimler arasındaki fark nispeten azdır. Bunun temel sebebi, nispi yükselti ve karasal etkiden dolayı iç kısımların zaten soğuk olmasıdır. Devrekani Çayı havzası ve Gökırmak'ın bir kolu olan Daday Çayı havzası ise sıcaklıkların nispeten arttı̆̆ yer olarak dikkati çeker.

Gerçek değerlere göre çizilen temmuz ayı izoterm haritasında; yine kıyı ve iç kısımlar, yüksek yerlerle alçak kesimler arasında sıcaklık farkları olduğu görülür (Şekil 7). Ancak bu fark kıyı ile içerideki platoluk saha arasında, kış aylarındaki kadar keskin değildir. Karasal iç kısımlar, yüksek yerler hariç bırakılırsa, kıyı sıcaklıklarına yakın değerler gösterir. Kıyıdaki istasyonlarda $22{ }^{\circ} \mathrm{C}$ civarında seyreden sıcaklık ortalamaları, içerdeki Kastamonu depresyonunda $20{ }^{\circ} \mathrm{C}$ civarındadır. Çevredeki dağların sıcaklık değerleri yüksekliğe bağı olarak $10{ }^{\circ} \mathrm{C}$ ye kadar geriler. Küre Dağları'nın kuzeye bakan kesimlerinde daha hızlı bir düşüş gözlenir. Bu durum gelen hava kütlelerinin daha çabuk soğuması ve kararlı hale geçmesi sonucunu doğurur. Güneyde ise adiyabatik olarak ısınarak, bu devrede sıcaklıkların yükselmesinde etkili olur. Devrekani ve Daday havzalarında sıcaklıklar $16^{\circ} \mathrm{C}$ ile $20^{\circ} \mathrm{C}$ arasında seyreder.

Ortalama sıcaklığın yıl içindeki dağılımında, Küre Dağları önemli rol oynar. Hava kütlelerin geçişini tanzim etmesi, kış mevsiminde içerideki sahalarda sıcaklığın yükselmesini engeller. Kısa mesafede sıralanan dağlar bir coğrafi engel olmakla beraber, aynı zamanda önemli yükseklikleri oluşturur. Bu durum, iç kısımlarda karasal etkiyi körükler, doğal bir sonuç olarak da yazların daha sıcak, kışlarında daha soğuk geçmesini sağlar.

Sıcaklık değerlerinin $0{ }^{\circ} \mathrm{C}^{\prime}$ nin alttna düştüğü günler donlu günler kategorisine girer. İnceleme sahasında bu durumu etkileyen en önemli faktörler kara-deniz dağılımı, yükseklik ve yeryüzü şekillerinin uzanışıdır. Kıyı istasyonlarında sıcaklıklar $0{ }^{\circ} \mathrm{C}$ 'nin altına kasım ayından itibaren düşer, mayıstan itibaren ise donlu gün görülmez. Cide'de yıllık 19,6, İnebolu'da ise 17,7 gün donlu gün vardır. Karasallığın etkisindeki Kastamonu'da ekim ayı ile başlayan donlu günler mayıs sonuna kadar devam eder. Toplamda, yıllık 107,4 günü bulur. En fazla donlu gün yaşanan aylar, Cide ve İnebolu'da ocak ve şubat ayları olarak görülürken, Kastamonu'da aralık ve ocak aylarıdır (Tablo 5, Şekil 8).

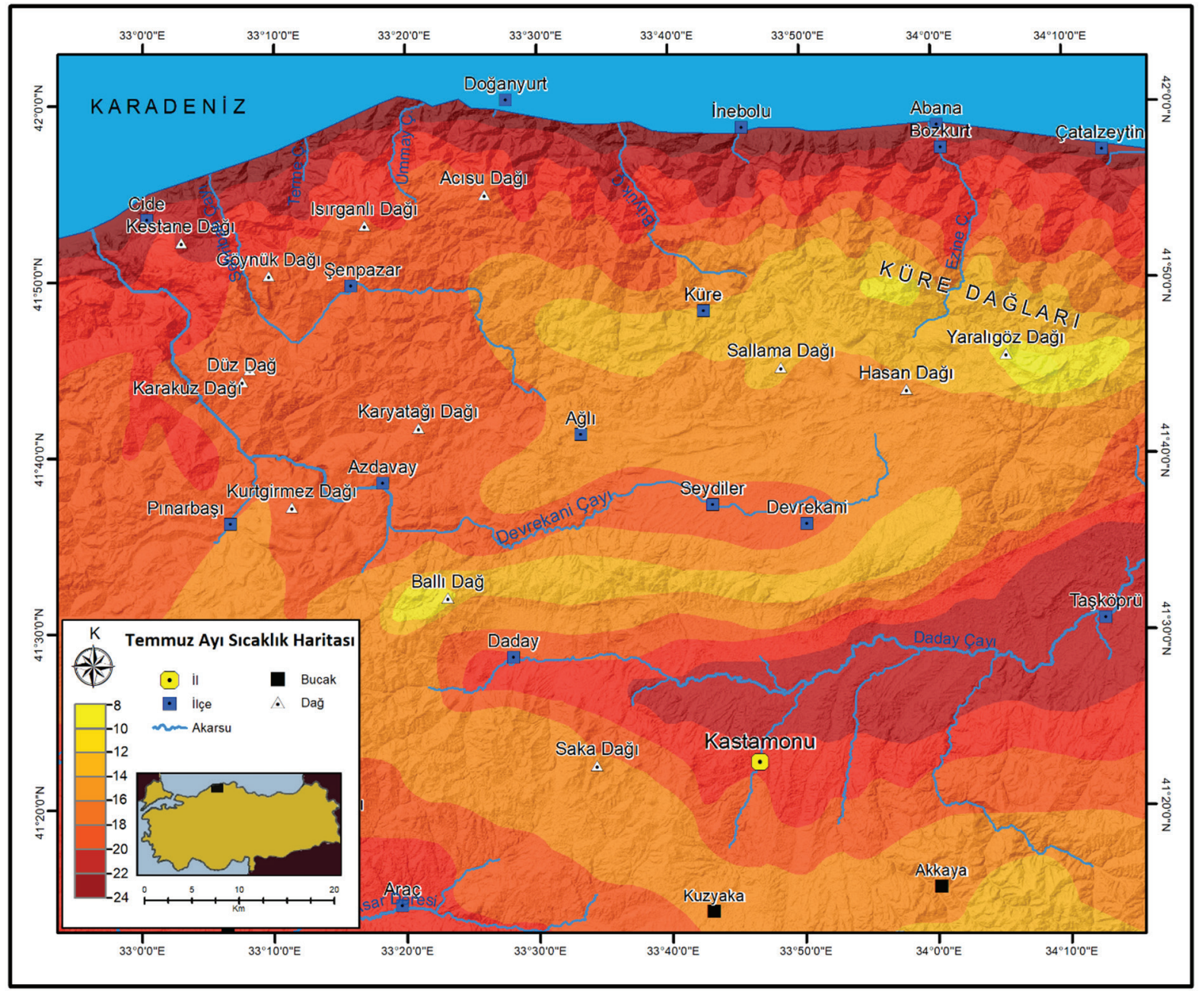

Şekil 7. İnceleme sahasının temmuz ayı ortalama sıcaklıklarına göre hazırlanan izoterm haritası $\left({ }^{\circ} \mathrm{C}\right)$.

Figure 7. Isotherm map of the mean temperatures in July of the study area $\left({ }^{\circ} \mathrm{C}\right)$. 
Tablo 5. Cide, İnebolu ve Kastamonu'da aylara göre donlu gün sayısı.

Table 5. Number of frozen days by the months at Cide, Inebolu and Kastamonu weather stations.

\begin{tabular}{|c|c|c|c|c|c|c|c|c|c|c|c|c|c|}
\hline İstasyon & 0 & Ş & $\mathbf{M}$ & $\mathbf{N}$ & $\mathbf{M}$ & $\mathbf{H}$ & $\mathbf{T}$ & A & E & E & K & A & Yillık \\
\hline Cide & 5,8 & 6,6 & 2,9 & 0,3 & 0,0 & & & & & & 0,8 & 3,2 & 19,6 \\
\hline İnebolu & 6,0 & 6,1 & 3,1 & 0,1 & & & & & & & 0,3 & 2,1 & 17,7 \\
\hline Kastamonu & 25,9 & 21,7 & 17,8 & 5,0 & 0,4 & & & & 0,0 & 2,6 & 12,0 & 22,0 & 107,4 \\
\hline
\end{tabular}

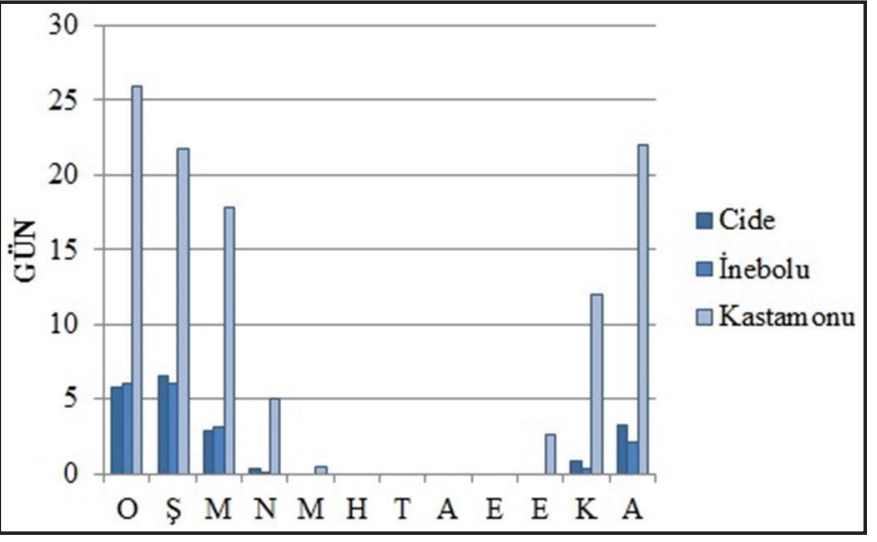

Şekil 8. Cide, İnebolu ve Kastamonu'da donlu gün sayılarının aylara dağılımı. Figure 8. Number of frozen days by the months at Cide, Inebolu and Kastamonu weather stations.

Don olaylarının mevsimlere dağılışına incelendiğinde, soğuk hava kütlelerinin kalış sürelerine bağlı olarak kış mevsimi ve etrafindaki aylar, don olaylarının görüldüğü aylar olarak dikkati çekmektedir. Don olayı bitkiler için özellikle ilkbahar ve sonbaharda önem kazanır. İlkbahar donları, bitkinin çiçeklerinin, sürgünlerinin donmasına sebep olur. Sonbahar donları henüz olgunlaşmamış sürgünlere zarar verir (Dönmez, 1985). Genellikle kıyı kesiminde bitkilerin vejetasyon süreleri dışında etkili olduğu için tarımsal üretime bir zararı olmaz, ancak iç kısımlarda özellikle ilkbahar aylarında rastlanan don olaylarının olumsuz etkileri görülür.

\subsubsection{Rüzgâr şartları}

Bir yerdeki rüzgar durumu, o yerde rüzgarın çeşitli yönlerden esme sayılarının, bunların hızlarının ve hakim olan yönün tespiti ile ortaya konabilir. Rüzgârın esme durumunu, o yerde rüzgârın çeşitli yönlerden esme sayıları (frekansları) ortaya koyar. Rüzgâr hızı, rüzgârın saniyede metre cinsinden veya saatte deniz mili cinsinden ifade edilir. Hakim rüzgar yönünü ise, rüzgar gülleri gösterir. Bir rüzgar gülü üzerinde hakim rüzgar yönü, boyu en uzun yön, yani rüzgar esme sayısının en fazla olduğu yöndür. Bununla beraber, hakim rüzgar yönünü tayin için kullanılan formüller de vardır. Bunlardan biri olan Rubinstein formülü, hakim rüzgar istikametini, belirli yönlere bağlı olmadan, derece cinsinden verdiği gibi, bu yönlerden esen rüzgarın rüzgarın esiş frekansını da verir (Dönmez, 1984).

Inceleme sahasındaki istasyonların rüzgâr esme sayıları ve frekanslarını gösteren tablo incelendiğinde (Tablo 6) şu sonuçlar ortaya çıkar: Cide'de en fazla GB yönündeki rüzgârlar \% 22,4 frekansa sahiptir. Bunu \% 16,7 ile KD, \% 13 ile G yönlerinden esen rüzgârlar takip eder. En düşük esme sıklığına sahip rüzgârlar \% 8,2 frekans ile KB yönündedir. İnebolu'da $\mathrm{G}$ yönündeki rüzgârlar \% 38 değerle, diğer yönlere göre ol- dukça fazla esme sıklığına sahiptir. Diğer yönlerden esen rüzgârların frekansları çok düşüktür; K'den \% 3,5 frekans, KB den ise \% 3,4 frekans kaydedilmiştir. Kastamonu'nun rüzgâr frekanslarında, özellikle karşıt yönlü rüzgârların esme sayıları daha fazladır. \% 23,4 ile G yönündeki rüzgârları, \% 19,4 ile GD ve $\% 18,9$ ile $K$ yönündeki rüzgârlar takip eder. $B, G D, K B$ yönleri birbirine yakın değerler gösterir ve $\% 6$ civarında frekansa sahiptir. Rüzgârların hangi yönden daha sık estiği, bu iş için hazırlanan rüzgâr güllerinden daha net anlaşılır (Şekil 9). Cide'nin rüzgâr gülündeki esme sayılarının birbirine yakın olması, yıl boyunca bu bölgeyi etkileyen basınç merkezlerinin çok yer değiştirmediğini gösterir. İnebolu'nun rüzgâr gülüne bakıldığında yıl boyunca esen rüzgârların ağırlık payının G sektörde toplandığı görülür. Kastamonu'da ise esen rüzgârların ağırlığı G sektörde (G-GB) toplanır, buna en yakın sektör K'dir. Kastamonu ve İnebolu'nun rüzgâr gülleri, yıl boyunca bu alanlardaki basınç merkezlerinde büyük değişim olduğunu gösterir.

Rüzgâr hızını tespit için, hız kademelerine göre sınıflandırılmış Beaufort Iskalası kullanılır. Bu kademelerin doğru bir şekilde tespit edilebilmesi için günlük değerlerin kullanıldığı veriler gereklidir. MGM' nün aylık ve yıllık rüzgâr hızları sadece ortalamaları gösterir. Sahada görülen rüzgarların ortalama hızları $6 \mathrm{~m} / \mathrm{s}^{\prime}$ den aşağı olduğundan, bu rüzgarlar "hafif rüzgarlar" kategorisine girer. Cide'de esen rüzgarların yıllık ortalama hızı 2,1 m/s'dir. Birbirine çok yakın hızda olmakla birlikte, en hızlı estikleri mevsim 2,4 m/s ile kıştır. İnebolu'yu etkileyen rüzgarlar diğer istasyonlara nazaran daha hızlı esmektedir. Yıllık ortalama hız 3,6 m/s, en hızlı estikleri dönem ise kasım ile şubat arasındaki soğuk devredir. İnebolu ve $\mathrm{Ci}$ de'de rüzgar hızlarının Kastamonu'dan fazla olmasında, bu alanlarda rüzgarın hızını kesen herhangi bir topografik engelin olmamasından dolayıdır (Tablo 7). Kastamonu'ya yönelen rüzgarları önemli ölçüde Küre Dağları kesmektedir.

Tablo 6. Cide, İnebolu ve Kastamonu'nun yıllık rüzgâr esme sayıları ve frekansları.

Table 6. Number of wind blowing and frequencies at Cide, Inebolu and Kasta monu weather stations.

\begin{tabular}{ccccccc}
\hline \multirow{2}{*}{ Yön } & \multicolumn{2}{c}{ Cide } & \multicolumn{2}{c}{ Inebolu } & \multicolumn{2}{c}{ Kastamonu } \\
& Esme & Frekans \% & Esme & Frekans \% & Esme & Frekans \% \\
\hline N & 19672 & 9,8 & 19289 & 3,5 & 137550 & 18,9 \\
NE & 33718 & 16,7 & 52433 & 9,3 & 73926 & 10,2 \\
E & 19001 & 9,4 & 47015 & 8,4 & 60787 & 8,3 \\
SE & 22460 & 11,2 & 37221 & 6,7 & 48315 & 6,7 \\
S & 26130 & 13 & 215887 & 38,5 & 169699 & 23,4 \\
SW & 44932 & 22,4 & 81839 & 14,6 & 140668 & 19,4 \\
W & 18744 & 9,3 & 87699 & 15,6 & 44683 & 6,2 \\
NW & 16468 & 8,2 & 19069 & 3,4 & 50057 & 6,9 \\
Toplam & 201125 & $100 \%$ & 560452 & $100 \%$ & 725685 & $100 \%$ \\
\hline
\end{tabular}




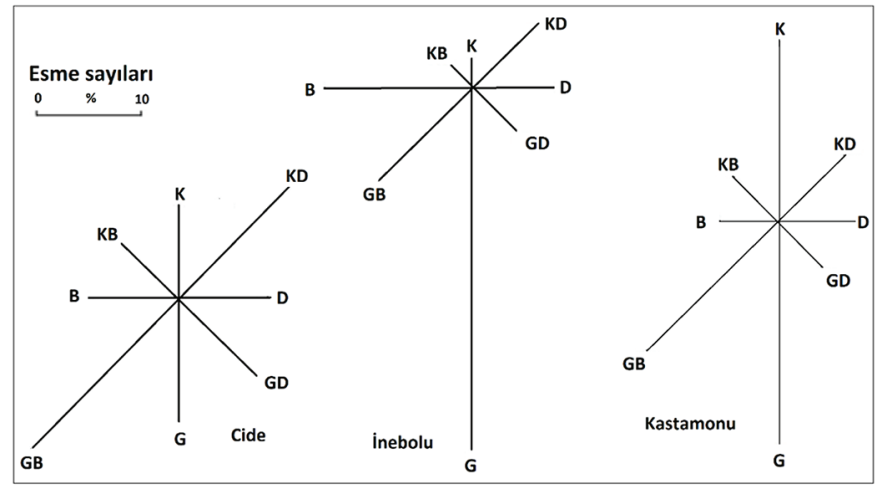

Şekil 9. Cide, İnebolu ve Kastamonu'da yıllık esme sayılarına göre rüzgâr gülleri. Figure 9. Wind diagram according to the number of annual blowing at Cide, Inebolu and Kastamonu weather stations. etki ederek, buradaki fiziki ve beşeri özellikleri tayin eder. Küre dağlarının kuzey ve güneyinde bulunan çeşitli kademelerdeki alanlar, farklı nemlilik ve bulutluluk şartlarıyla dikkati çekerler.

Belirli bir sıcaklıkta havada bulunan nemin, aynı sıcaklıkta havanın alabileceği nem miktarına oranına, bağıl (nispi) nem adı verilir. Başka bir ifadeyle havanın belirli sıcaklıkta belli bir nem kapasitesi vardır. Sınırın aşılması halinde yağış meydana gelir. Havadaki mevcut nem ile alabileceği nem arasındaki bu oran \% ile ifade edilir. Dolayısıyla bir yerin aldığı yağış, o yerdeki bağıl nem miktarı ile yakından ilgilidir. Sıcaklığın yüksek olduğu yerlerde havanın doyma noktasına ulaşabilmesi için daha fazla neme ihtiyacı vardır, yani su kaynağı yoksa bağıl nem düşer. Oysa sıcaklığın düşük olduğu yerlerde, havanın beslenme kaynağı varsa bağıl nem yükselir ve rahatlıkla yağış meydana gelir.

Tablo 7. Cide, İnebolu ve Kastamonu'nun Aylık Ortalama Rüzgar Hızları (m/s).

Table 7. The mean wind speed at Cide, Inebolu and Kastamonu weather stations $(\mathrm{m} / \mathrm{s})$.

\begin{tabular}{|c|c|c|c|c|c|c|c|c|c|c|c|c|c|}
\hline İstasyon & 0 & Ş & $\mathbf{M}$ & $\mathbf{N}$ & $\mathbf{M}$ & $\mathbf{H}$ & $\mathbf{T}$ & A & $\mathbf{E}$ & $\mathbf{E}$ & $\mathbf{K}$ & A & Yıllık \\
\hline Cide & 2,3 & 2,4 & 2,2 & 1,9 & 1,7 & 2,0 & 2,0 & 2,0 & 2,0 & 2,1 & 2,2 & 2,4 & 2,1 \\
\hline İnebolu & 4,0 & 3,9 & 3,6 & 3,1 & 2,7 & 3,0 & 3,2 & 3,5 & 3,8 & 3,8 & 4,0 & 4,0 & 3,6 \\
\hline Kastamonu & 1,2 & 1,4 & 1,5 & 1,5 & 1,3 & 1,2 & 1,2 & 1,2 & 1,1 & 1,1 & 1,1 & 1,1 & 1,2 \\
\hline
\end{tabular}

Rubinstein'a göre hazırlanan formül kullanılarak, esme sayılarından yararlanıp hakim rüzgar yönleri tespit edilmiştir. Buna göre Cide istasyonunda hâkim rüzgâr yönü $K 43,2^{\circ} D$ ve frekansı \% 27,4'tür. İnebolu'nun hakim rüzgar yönü G 11,6 B ile \% 62,1 frekansa sahiptir. Kastamonu istasyonunda, birinci hâkim rüzgâr yönü $\mathrm{G} 19^{\circ} \mathrm{B}$ ve frekansı \% 43 tür. İkinci hâkim rüzgâr yönü ise $K 18,9^{\circ} \mathrm{D}$ ve frekansı \% $29^{\prime}$ dur (Şekil 10).

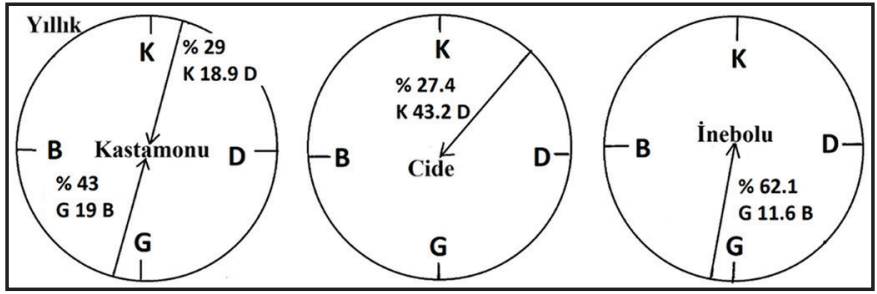

Şekil 10. İnceleme sahasındaki istasyonların Rubinstein formülüne göre hazırlanmış yıllık hakim rüzgar yönleri.

Figure 10. Annual prevailing wind directions according to the Rubinstein formula of the weather stations in the study area.

\subsubsection{Yağış şartları}

Bir bölgenin yağış özelliklerinin daha iyi anlaşılabilmesi için sıcaklıkla beraber, nem durumu ve bulutluluk şartlarının iyi bilinmesi gerekir. Böylece coğrafi yapıya bağlı olarak düşen yağış miktarı ve tipi, bunların aylara ve mevsimlere dağılımı gibi özellikleri analiz edilebilir. Bu manada yeryüzündeki bütün coğrafi muhitlerin kendine göre farklı özellikleri vardır. Karadeniz bölgesinin yağış durumu doğal şartlarına oldukça fazla
Kastamonu çevresinde, özellikle kıyılarla birlikte, dağlık alanlar bağıl nem miktarı olarak bu ikinci tanıma daha yakındır.

Deniz etkisinin sınırlı olarak sokulabildiği Kastamonu ile kıyı kesimindeki istasyonlar arasında bağıl nemin aylara göre dağılışında belirgin farklılıklar ortaya çıkmaktadır (Tablo 8, Şekil 11). Kıуı istasyonlarında neredeyse bütün aylarda bağı nem \% 70'in üzerindedir. Cide'de en yüksek olduğu aylarda (mayıs, haziran, temmuz, ağustos, eylül ve ekim) \% 75'e yakındır. En düşük oran \% 69,6 ile aralıktadır. İnebolu'da ise özellikle bahar aylarında bağıl nem değerleri çok yüksektir (örneğin, mayıs \%79). Her iki istasyonda sonbahar mevsiminde bağıl nem oranlarının yüksekliği ile yağış artışı arasında bir uyum vardır. Bu şekilde düzenli nem değerleri yine yıllık yağış rejimiyle de örtüşmektedir. Neticede kıyıdaki istasyonların bağıl nem oranları ile tipik Karadeniz iklimindeki nem oranları benzerdir. Bu istasyonlarda minimum değerlere en fazla kış aylarında rastlanır (aralık \% 6-7). Kastamonu'da yıllık ortalama \% 69,2'dir. Oysa kıyıdaki istasyonların en düşük olduğu ay bile bu değerden yüksektir. Kastamonu'nun bağıl nem oranları kış ve etrafindaki aylarda artmaktadır (aralık \%80,7). Yaz ayları en düşük bağıl nem oranlarına sahiptir (temmuz \% 58,9). Yani sıcaklıkların düşük olduğu dönemler aynı zamanda bağıl nemin yüksek olduğu dönemdir. Bu özellikler bize karasal iklimi hatırlatır. Kastamonu'da diğer iki istasyona göre bağıl neminin daha düşük olmasının sebepleri ise karasallık derecesinin daha fazla olmasının yanı sıra enlem derecesi ve sıcaklığa bağlı olarak yağış ihtimalinin düşmesidir.

Tablo 8. Cide, İnebolu ve Kastamonu'da ortalama bağıl nem ve minimum nemin aylara göre dağılımı (\%).

Table 8. Mean relative humidity and minimum humidity values by the months at Cide, Inebolu and Kastamonu weather stations (\%).

\begin{tabular}{|c|c|c|c|c|c|c|c|c|c|c|c|c|c|c|}
\hline İstasyon & Aylar & 0 & \$ & $\mathbf{M}$ & $\mathbf{N}$ & $\mathbf{M}$ & $\mathbf{H}$ & $\mathbf{T}$ & A & 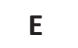 & $\mathbf{E}$ & $\mathbf{K}$ & A & Yıllık \\
\hline \multirow{2}{*}{ Cide } & Orta Bağıl N. & 71,4 & 71,9 & 70,9 & 73,4 & 75,8 & 74 & 74,1 & 74,4 & 75,3 & 75,8 & 72,4 & 69,6 & 73,2 \\
\hline & Min. Nem & 13 & 8 & 10 & 11 & 10 & 19 & 16 & 23 & 23 & 12 & 12 & 6 & 6 \\
\hline \multirow{2}{*}{ İnebolu } & Orta Bağıl N. & 73,5 & 74,6 & 75,9 & 77,2 & 79 & 75,4 & 73,2 & 73,5 & 75,4 & 77,5 & 74,2 & 72,4 & 75,2 \\
\hline & Min. Nem & 16 & 16 & 11 & 10 & 21 & 22 & 27 & 14 & 19 & 23 & 9 & 7 & 7 \\
\hline \multirow{2}{*}{ Kastamonu } & Orta Bağıl N. & 78,7 & 74,1 & 68,6 & 65,5 & 65,8 & 64,1 & 58,9 & 59,6 & 65,1 & 71,7 & 77,1 & 80,7 & 69,2 \\
\hline & Min. Nem & 17 & 10 & 11 & 11 & 8 & 11 & 10 & 6 & 5 & 12 & 17 & 16 & 5 \\
\hline
\end{tabular}




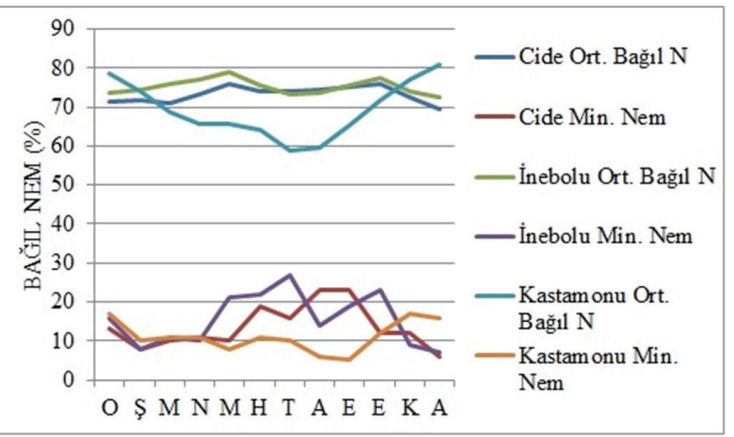

Şekil 11. Cide, İnebolu ve Kastamonu'da ortalama bağıl nem ve minimum nemin aylara göre dağılımı (\%)

Figure 11. Mean relative humidity and minimum humidity values by the months at Cide, Inebolu and Kastamonu weather stations (\%).

Su buharının gökyüzünde belirli kademelerde yoğunlaşmasıyla meydana gelen bulutlar, iklim olayları bakımından oldukça önemlidir. Yağışa meydan vermesinin yanı sıra güneş ışınlarını tutarak sıcaklık dağılışında da etkili olur. Yükseklik ve oluşturdukları şekillere göre çeşitli isimler alır ve her birinin yağış getirme ihtimali aynı değildir. Gökyüzünde görülebilir alanı kapatma oranlarına göre açık gün, bulutlu gün ve kapalı gün olarak isimler verilir. Alanın tamamı 10 olarak düşünülürse, 0-2 arası açık gün, 2-8 arası bulutlu gün, 8-10 arası kapalı gün olarak değerlendirilir. Türkiye'de bulutluluğun en yüksek olduğu bölge Karadeniz Bölgesi'dir. Dolayısıyla Karadeniz Bölgesi'nin yağışlı ve serin olmasının yanı sıra buharlaşma ve güneşlenme sürelerinin azalmasında bu durumun payı vardır. İnceleme sahasındaki istasyonların yıllık ortalama bulutluluk değerleri birbirine çok yakındır. Cide'de 5,4, İnebolu'da 5,6 ve Kastamonu'da 5,5'tir.

Cide'de yaz aylarında bulutluluk oranının düştüğü görülmektedir (Tablo 9). Haziran, temmuz, ağustos ve eylül aylarında bulutluluk oranları 4 günün altındadır. Bu dönem içinde minimum bulutluluk 3,1 ile ağustos ayındadır. Kış aylarında bulutluluk oranları daha yüksektir. En yüksek bulutluluk değerine sahip aylar; aralık $(6,9)$, ocak $(7,2)$ ve şubattır $(6,9)$. Ortalama açık gün sayıları, bulutlu gün sayıları ile tezat teşkil eder. Yani bulutlulu- ğun azaldığı yaz ayları açık gün sayısı fazladır. Haziran, temmuz, ağustos ve eylül aylarında açık gün sayısı 10 günü geçer. En fazla açık gün 14,6 ile ağustos ayındadır. Kış aylarında ise 4 günün altına geriler. Ocak ayında 2,9 gündür. Kapalı gün sayıları kasım ayından itibaren 12,8 in üzerine çıkar, ocak ayında 14,9 a ulaşır. Illkbahar aylarında düşmeye devam eder ve temmuz-ağustos aylarında 2,7'yi bulur.

Inebolu'da, diğer kıyı istasyonu olan Cide'ye benzer bir durum gözlenir (Tablo 10). Yine yaz aylarında bulutluluk oranının düştüğü görülür. Temmuz ve ağustos aylarında ortalama bulutluluk 4'ün altındadır. Bu dönem içinde minimum bulutluluk 3,3 ile temmuz ayındadır. Kış aylarında bulutluluk yükselir; en yüksek bulutluluk değerine sahip aylar; $\operatorname{aralık}(7,0)$, ocak $(7,2)$ ve şubattır $(7,2)$. Ortalama açık gün sayıları, bulutlu gün sayıları ile ters orantlıdır. Yani bulutluluğun azaldığı yaz aylarında, Cide'de olduğu gibi açık gün sayısı daha fazladır. Temmuz ve ağustos aylarında açık gün sayısı 10 günü geçer. En fazla açık gün 11,9 ile temmuz ayındadır. Kış aylarında ise 4 günün altına geriler. Ocak ayında 2,2 gündür. Kapalı gün sayıları kasım ayından itibaren 11,1'in üzerine çıkar, ocak ayında 15,5'a ulaşır. Mart - nisan devresinde yine yüksektir, ilkbahar sonlarında belirgin olarak düşmeye başlar ve temmuz ayında 1,7'yi bulur. Cide ve İnebolu'da bulutluluğun yüksek oranlarda olmasının sebeplerinin başında, Karadeniz'in varlığının ve Küre Dağları'nın yoğunlaşmayı arttırarak bulut oluşumuna yol açmasının önemi büyüktür.

Kastamonu'da karasal iklim bölgelerinden farklı olarak bulutluluk yüksektir. Yaz aylarını oluşturan temmuz, ağustos ve eylül aylarında bulutluluk oranları 4'ün altındadır. Bu dönem içerisinde minimum bulutluluk 3,2 ile ağustos ayında görülmektedir. Kış aylarında bulutluluk oranı daha yüksektir (aralık 7,4, ocak 7,3 ve şubat 6,9). Açık günler sayısının en az olduğu aylar aralık, ocak ve şubat ayındadır. Bulutluluğun en yüksek olduğu ekim-nisan ayları arasında dönemde, açık günler sayısı oldukça düşüktür ve mayıs-eylül ayları arası dönemde ise açık günler sayısı oldukça fazladır. Kapalı gün sayısı kış aylarında artar; aralık 16,8 değer ile en yüksek kapalı güne sahip aydır (Tablo 11).

Tablo 9. Cide'de ortalama bulutluluk, ortalama açık, bulutlu ve kapalı gün sayılarının aylara dağılımı.

Table 9. Number of the mean cloudiness, sunny, cloudy and sunless days by the months at Cide weather station.

\begin{tabular}{|c|c|c|c|c|c|c|c|c|c|c|c|c|c|}
\hline Cide & 0 & ş & M & $\mathbf{N}$ & M & $\mathbf{H}$ & $\mathbf{T}$ & A & E & E & K & A & Yillık \\
\hline Ort.Bulutluluk & 7,2 & 6,9 & 6,3 & 6,1 & 4,9 & 3,9 & 3,2 & 3,1 & 3,9 & 5,3 & 6,5 & 6,9 & 5,4 \\
\hline Ort.Açık Gün & 2,9 & 3,0 & 4,6 & 5,2 & 8,5 & 10,4 & 13,9 & 14,6 & 11,2 & 7,8 & 4,7 & 3,8 & \\
\hline Ort.Bulutlu Gün & 10,3 & 9,9 & 12,0 & 12,4 & 13,4 & 14,2 & 14,4 & 13,8 & 13,8 & 13,9 & 11,1 & 11,7 & \\
\hline Ort.Kapalı Gün & 14,9 & 12,6 & 11,4 & 11 & 7,6 & 3,9 & 2,7 & 2,7 & 5 & 9,3 & 12,8 & 14,1 & \\
\hline
\end{tabular}

Tablo 10. İnebolu'da ortalama bulutluluk, ortalama açık, bulutlu ve kapalı gün sayılarının aylara dağılımı.

Table 10. Number of the mean cloudiness, sunny, cloudy and sunless days by the months at Inebolu weather station.

\begin{tabular}{|c|c|c|c|c|c|c|c|c|c|c|c|c|c|}
\hline İnebolu & 0 & Ş & M & $\mathbf{N}$ & M & H & $\mathbf{T}$ & A & $\mathbf{E}$ & $\mathbf{E}$ & K & A & Yıllık \\
\hline Ort.Bulutluluk & 7,2 & 7,2 & 6,9 & 6,5 & 5,7 & 4,2 & 3,3 & 3,4 & 4,2 & 5,5 & 6,3 & 7,0 & 5,6 \\
\hline Ort.Açık Gün & 2,5 & 2,2 & 3,0 & 3,3 & 4,9 & 8,3 & 11,9 & 11,2 & 8,5 & 6,4 & 3,8 & 2,8 & \\
\hline Ort.Bulutlu Gün & 12,5 & 11,6 & 13,1 & 14,8 & 17,3 & 18,0 & 16,9 & 17,4 & 17,3 & 15,6 & 155,1 & 14,0 & \\
\hline Ort.Kapalı Gün & 15,5 & 14 & 14,4 & 11,3 & 8,3 & 3,2 & 1,7 & 1,8 & 3,7 & 9,1 & 11,1 & 14,2 & \\
\hline
\end{tabular}

Tablo 11. Kastamonu'da ortalama bulutluluk, ortalama açık, bulutlu ve kapalı gün sayılarının aylara dağılımı.

Table 11. Number of the mean cloudiness, sunny, cloudy and sunless days by the months at Kastamonu weather station.

\begin{tabular}{|c|c|c|c|c|c|c|c|c|c|c|c|c|c|}
\hline Kastamonu & 0 & \$ & $M$ & $\mathbf{N}$ & $M$ & $\mathbf{H}$ & $\mathbf{T}$ & A & $\mathbf{E}$ & $\mathbf{E}$ & K & A & Yıllık \\
\hline Ort.Bulutluluk & 7,3 & 6,9 & 6,4 & 6,2 & 5,7 & 4,5 & 3,3 & 3,2 & 3,8 & 5,0 & 6,2 & 7,4 & 5,5 \\
\hline Ort.Açık Gün & 2,6 & 2,6 & 3,9 & 3,5 & 3,7 & 6,6 & 12,2 & 13,3 & 10,9 & 7,8 & 4,4 & 2,3 & \\
\hline Ort.Bulutlu Gün & 12,0 & 12,8 & 15,1 & 16,5 & 19,4 & 19,7 & 16,8 & 15,6 & 15,6 & 15,7 & 14,6 & 11,9 & \\
\hline Ort.Kapalı Gün & 16,4 & 12,9 & 12 & 9,9 & 7,9 & 3,7 & 2 & 3,5 & 3,5 & 7,5 & 11 & 16,8 & \\
\hline
\end{tabular}


Tablo 12. Cide, İnebolu ve Kastamonu'da yıllık ortalama yağış miktarlarının aylara dağılımı (mm).

Table 12. The mean annual rainfall by the months at Cide, Inebolu and Kastamonu weather stations ( $\mathrm{mm})$.

\begin{tabular}{|c|c|c|c|c|c|c|c|c|c|c|c|c|c|}
\hline İstasyon & 0 & Ş & $\mathbf{M}$ & $\mathbf{N}$ & $M$ & $\mathbf{H}$ & $\mathbf{T}$ & A & $\mathrm{E}$ & E & K & A & Yillık \\
\hline Cide & 88,5 & 67,5 & 62,9 & 40,8 & 45,9 & 57,4 & 56,9 & 59,6 & 92,0 & 143,7 & 132,7 & 120,2 & 968,1 \\
\hline İnebolu & 109,3 & 84,6 & 78,0 & 47,5 & 49,5 & 50,4 & 47,2 & 56,3 & 91,7 & 138,8 & 126,0 & 138,2 & 1017,5 \\
\hline Kastamonu & 30,1 & 27,3 & 34,6 & 51,9 & 74,5 & 70,7 & 31,8 & 30,8 & 30,3 & 35,2 & 29,3 & 33,7 & 480,2 \\
\hline
\end{tabular}

Yıllık ortalama bulutlu günler Cide'de 150,9 gün, İnebolu'da 183,6 gün ve Merkez'de 185,7 gündür. Bulutlu günler sayısının aylara göre dağılımında da farklılıklar görülmektedir. İstasyonlara göre en az ve en fazla bulutlu günlerin görüldüğü aylar şöyledir: Cide'de 9,9 (şubat) -14,4 (temmuz) gün, İnebolu'da 11,6 (şubat) - 18,0 (haziran) gün ve Merkez'de 11,9 (aralık) $-19,7$ (haziran) gündür.

Karadeniz Bölgesi ülkemizin en fazla yağış alan yerlerinin başında gelir. Bunun temel sebebi kuzey yönlü hava kütlelerinin kat ettiği Karadeniz olmakla birlikte, bölge tamamında dengeli bir dağılış olduğu söylenemez. Yüzey şekillerinin uzanışı ve yükseltisi bu konuda belirleyicidir. Nitekim, gerisinde duvar gibi yükselen Küre dağlarının varlığı, kıyıda yağışların 1000 mm'nin üzerine çıkmasına sebep olur. Bu durumda inceleme sahasındaki istasyon verilerine bakıldığında, yıllık yağış miktarları büyük farklılıklar gösterir (Tablo 12, Şekil 12). Özellikle kıyı ve iç kesimdeki istasyonlar arasındaki yıllık yağış farkının oldukça fazla olduğu görülür. Cide'de 968,1 mm olan yağış miktarı, İnebolu'da 1017,5 mm ve Kastamonu'da 480,2 mm'dir. Bu değerler yükselti ve engebenin artmasına bağlı olarak daha da artmaktadır. Çalışma alanındaki istasyonlardan en fazla yağış alan istasyon 1017,5 mm ile İnebolu'dur. En az yağış alan istasyon ise 480,2 mm ile Kastamonu istasyonudur. İnebolu'nun yıllık yağış miktarı, Kastamonu'nun yağış miktarının iki katından fazladır.

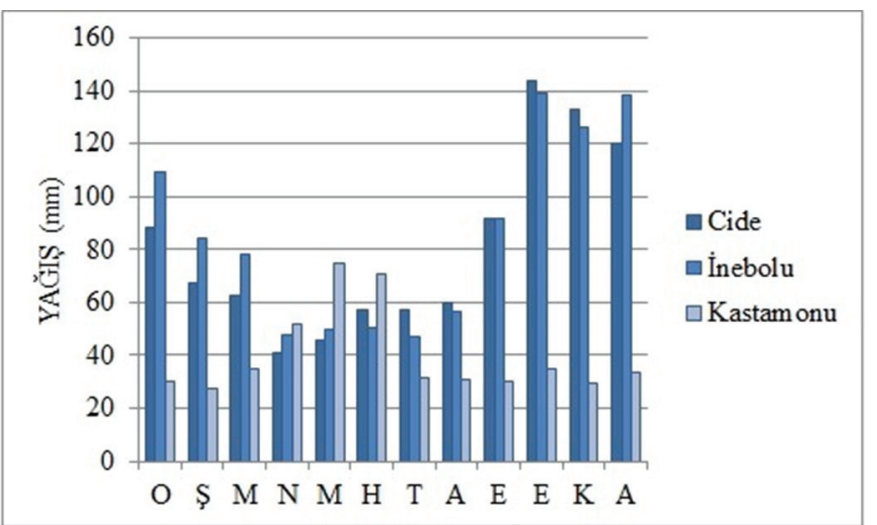

Şekil 12. Cide, İnebolu ve Kastamonu'da yıllık ortalama yağış miktarlarının aylara dağııımı (mm).

Figure 12. The mean annual rainfall by the months at Cide, Inebolu and Kastamonu weather stations $(\mathrm{mm})$.
İnceleme sahasında yıllık ortalama yağış dağılışını gösteren harita incelendiğinde (Şekil 13), sadece istasyonların olduğu yere ait değil, diğer alanlardaki durumu da açıkça görmek mümkün olur. Yağışın farklı dağılışının temel sebebi denize uzaklık ve yeryüzü şekilleridir. Kıyı gerisinde birden yükselen Küre dağları Karadeniz'e paralel uzanmasının yanı sıra çok az geçit verir. Bu durum, hava kütlelerinin daha çok kıyıda nemin bırakmasına, duldasında kalan güneyindeki yerleşim merkezlerine sınırlı miktarda nemli havanın geçmesine yol açar. Kıyıdan itibaren Cide'de 968 mm, İnebolu'da 1017 mm, Bozkurt'ta 1111 mm olan yağış değerleri, hızlı bir şekilde yükselerek zirvelerde 2000 mm'yi aşar. Güney yamaçlarda hızlı bir düşüşle kısa mesafede 500 mm civarına kadar iner. Bu düşüşte bakı etkisinin yanı sıra hava kütlelerinin güney yamaçlarda alçalmasının payı büyüktür. Yükseltiye bağlı olarak Pınarbaşı'da 657 mm, Azdavay'da 563 mm, Devrekani ve Kastamonu'da 480 mm yağış kaydedilmiştir. İç kısımlarda yüksek olan dağlık kesimler yine yağışların fazla olduğu yerlerdir. Buralarda yağışın artmasında hava kütlelerinin tekrar yükselip doyma noktasına ulaşmasının payı vardır. Yağış miktarının 1000-1500 mm arasında seyrettiği bu alanlar Ballıdağ ve Ilgaz Dağları gibi önemli yüksekliklerdir.

Yağış miktarı gibi yağış rejimi, yani yağışın aylara ve mevsimlere dağılışı da önemlidir. Özellikle canlıların kullanabilmesi, toprağın suyu kabul etmesi, yeraltı sularının beslenmesi gibi birçok olay yağışların yıl içinde dengeli dağılmasına bağlıdır. Aylara göre dağılımda en düşük yağış İnebolu'da $(47,2 \mathrm{~mm})$ temmuz, Cide'de (40,8 mm) nisan, Kastamonu'da (20,8 mm) ise ağustos ayında tespit edilmiştir. En fazla yağış düşen aylar Kastamonu'da $(74,5 \mathrm{~mm})$ mayıs, Cide $(143,7 \mathrm{~mm})$ ve İnebolu'da $(138,8 \mathrm{~mm})$ ise ekim aylarıdır. Genel olarak kış ve civarındaki aylarda yağışlarda artı̧, yaz aylarında ise bir azalma görülmektedir. Bunun temel sebebi bölgeyi ziyaret eden nemli hava kütlelerinin daha çok kış mevsiminde gelmesi, yazın ise kuzeye doğru çekilmesidir. Bununla birlikte kıyı istasyonları ile içerideki istasyonların aylık yağış değerleri arasında önemli farklar görülmektedir.

Yağışın mevsimlere dağılış oranlarına bakıldığında (Tablo 13, Şekil 14), kıyıda yer alan istasyonlarda yağışın en fazla sonbaharda düştüğü görülür (Cide \%38,0 ve İnebolu \%34,1). Karadeniz ikliminde sonbahar yağışlarının payı fazladır. Kastamonu istasyonunda \% 32,4 ile en fazla yağış İlkbahar mevsiminde

Tablo 13. Cide, İnebolu ve Kastamonu'da yıllık yağışın mevsimlere dağılışı (mm).

Table 13. The mean annual rainfall by the seasons at Cide, Inebolu and Kastamonu weather stations ( $\mathrm{mm}$ ).

\begin{tabular}{lcccc}
\hline İstasyon & Kış & ilkbahar & Yaz & Sonbahar \\
\hline Cide & 276,2 & 149,6 & 173,9 \\
İnebolu & 332,1 & 175,0 & 153,9 \\
Kastamonu & 91,1 & 160,4 & 356,5 \\
\hline
\end{tabular}




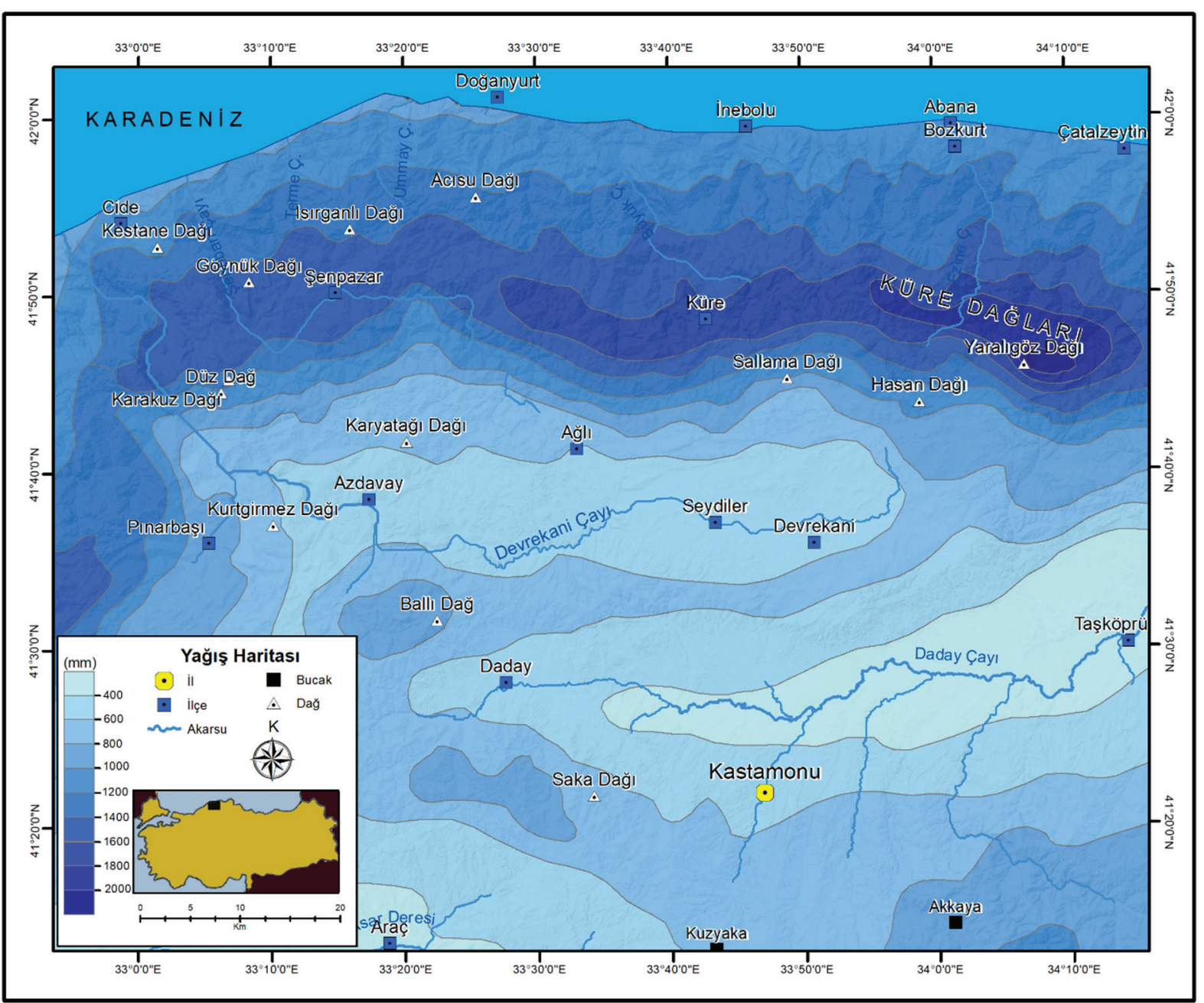

Şekil 13. İnceleme sahasında yıllık ortalama yağışın dağılışı (mm).

Figure 13. The mean annual rainfall by the months in the study area ( $\mathrm{mm})$.

düşmektedir. Bu durum Kastamonu'nun karasal iklime yakınIığının bir göstergesidir. En az yağışın düştüğü mevsim ise; İnebolu'da $(\% 15,1)$ yaz, Cide'de $(\% 15,5)$ ilkbahardır. Her iki istasyonda ilkbahar ve yaz mevsimlerinde yağış miktarları düşük ve birbirine yakındır. Kastamonu $(\% 19,1)$ istasyonunda ise en az yağış kış mevsiminde düşmektedir. Buradan anlaşılacağı üzere İnebolu ile Cide benzer yağış değerlerine sahiptir. Kıyıdan uzaklaştıkça yağış rejiminin belirgin şekilde değişikliğe uğradığı görülmektedir. Küre dağlarının kuzeye bakan kısımlarında görülen Karadeniz yağış rejimi özellikleri, iç kısımlara geçildiğinde değişmektedir. Bu alanlar daha çok İç ve Doğu Anadolu yağış rejiminin bir karışımı şeklindedir. Yağış miktarlarının başta mayıs ayı olmak üzere ilkbahar içerisinde artması buna işarettir.
Sıcaklık $0^{\circ} \mathrm{C}^{\prime}$ nin altında olduğu zamanlarda havadaki su buharının buz kristalleri haline yoğunlaşmasıyla meydana gelen kar yağışı; oldukça faydalı bir yağıştır. Toprak için devamlı bir su kaynağı olmasının yanı sıra akarsu ve yeraltı sularını yıl boyunca besler. Topraktaki tohumları düşük sıcaklıklara karşı korur ve hava sıcaklığını $0{ }^{\circ} \mathrm{C}^{\prime}$ ye yaklaştırır. Bu bakımdan bir bölge için kar yağışlarının, sayısı, yerde kalma süresi, kalınlığı, ne zaman yağdığı ve kalktığı oldukça önemlidir. Kar yağışları aynı zamanda insan faaliyetlerini de önemli derecede etkiler. Erimesi hızlı olduğunda sel baskınlarına yol açabilir.

Inceleme sahasında kar yağışlı günlerin yıllık ortalama sayısı 18-38 gün arasında değişmektedir. Yıl içinde kar yağışlı gün

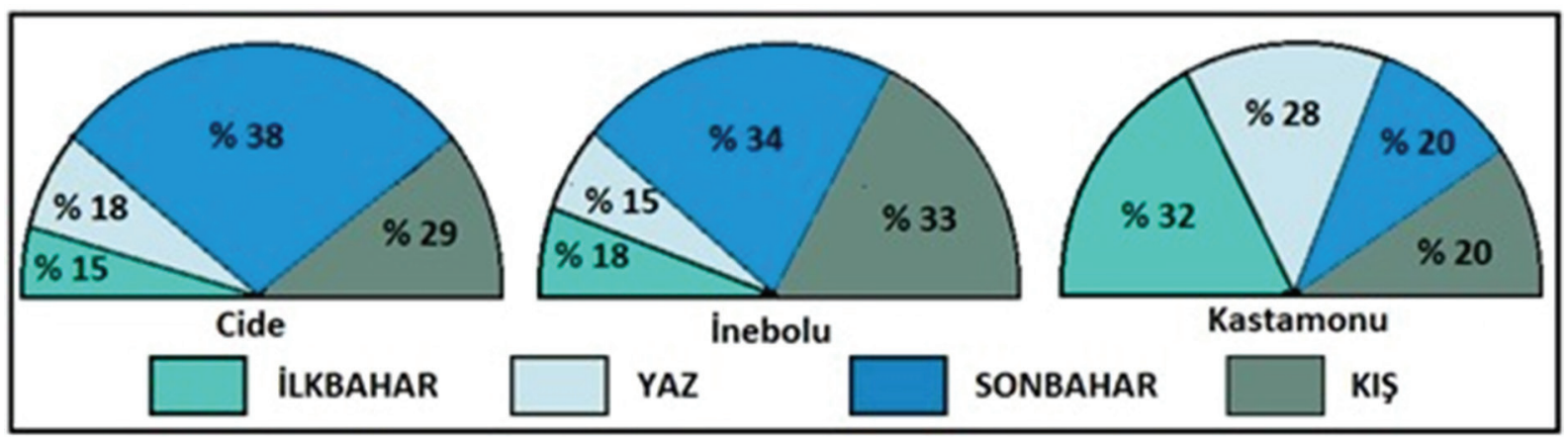

Şekil 14. Inceleme sahasındaki istasyonlarda yağışın mevsimlere dağılışı (\%).

Figure 14. The mean annual rainfall by the seasons of the weather stations in the study area (\%). 
Tablo 14. Cide, İnebolu ve Kastamonu'da yıllık ortalama kar yağışlı gün, karla örtülü gün sayıları ve kar kalınlığı (cm).

Table 14. The mean annual snowy days, snow-covered days and snow thickness at Cide, Inebolu and Kastamonu weather stations (cm).

\begin{tabular}{|c|c|c|c|c|c|c|c|c|c|c|c|c|c|c|}
\hline & & 0 & Ş & M & $\mathbf{N}$ & M & $\mathbf{H}$ & $\mathbf{T}$ & A & $\mathbf{E}$ & $\mathbf{E}$ & K & A & Yillık \\
\hline & Kar Yağışlı Gün & 5,1 & 5,5 & 2,1 & 0,3 & & & & & & 0,0 & 1,9 & 3,6 & 18,7 \\
\hline \multirow[t]{3}{*}{ Cide } & Karla Örtülü Gün & 1,5 & 1,5 & 0,6 & & & & & & & & & 0,9 & \\
\hline & Kar Kalınlığı & 35 & 26 & 23 & & & & & & & & & 12 & 35,0 \\
\hline & Kar Yağışlı Gün & 5,2 & 5,5 & 3,5 & 0,3 & & & & & & 0,0 & 1,3 & 2,9 & 18,7 \\
\hline \multirow[t]{3}{*}{ İnebolu } & Karla Örtülü Gün & 4,1 & 4,6 & 1,8 & 0,0 & & & & & & & 0,3 & 1,5 & \\
\hline & Kar Kalınlığı & 67 & 146 & 138 & 3 & & & & & & & 24 & 34 & 146,0 \\
\hline & Kar Yağışlı Gün & 10,6 & 9,0 & 6,9 & 1,8 & 0,0 & & & & & 0,2 & 2,6 & 6,4 & 37,5 \\
\hline \multirow[t]{2}{*}{ Kastamonu } & Karla Örtülü Gün & 14,3 & 9,9 & 3,9 & 0,4 & & & & & & 0,0 & 1,1 & 8,0 & \\
\hline & Kar Kalınlığı & 53 & 47 & 37 & 21 & & & & & & 1 & 24 & 40 & 53 \\
\hline
\end{tabular}

sayısı Cide ve İnebolu'da 18,7 gün, Kastamonu'da ise 37,5 gündür (Tablo 14 ve Şekil 15). Cide'de en fazla kar yağışının görüldüğü ay 5,5 gün ile şubat ayıdır. Ocak 5,1 gün ve aralık 3,6 gün ile kar yağışının diğer fazla görüldüğü aylardır. İnebolu'da en fazla kar yağışının görüldüğü ay 5,5 gün ile Cide'de olduğu gibi yine şubat ayıdır. Kar yağışının fazla olduğu diğer aylar ise 5,2 günle ocak ve 2,9 günle aralıktır. Kastamonu'da ise en fazla kar yağışı 10,6 gün ile ocak ayında görülür. Bunu 9,0 gün ile şubat ve 6,9 ile mart ayı takip eder. Haziran-temmuz-ağustos aylarının dahil olduğu yaz döneminde kar yağışı görülmemektedir.

Cide'de kar yağışları kasım ayından itibaren başladığı halde, bu ayda toprağın karla örtülü olmadığı görülür. Sıcaklıklar henüz düşük seyretmediği bu dönemi takiben aralık ayında karla örtülü gün sayısı 0,9'dur. Karın yerde kalma süresi uzun olmamakla birlikte, kar kalınlığı 12 cm'ye ulaşır. Kış mevsimin sonraki aylarında karla örtülü gün sayısı pek artmadığı halde kar kalınlığı ocakta $35 \mathrm{~cm}$, şubatta ise $26 \mathrm{~cm}$ 'dir. Mart ayında toprakta kar örtüsü oluşur, ancak takip eden aylarda kar yağışının etkisini yitirmesiyle birikim mümkün olmaz. İnebolu'da yıllık karlı gün sayısı Cide ile aynı olmasına rağmen hem karla örtülü gün sayısı, hem de kar kalınlığı fazladır. Kasımda başlayan kar yağışları mayısa kadar devam eder. Karın yerde kalma süresi ocakta 4,1 şubatta ise 4,6'dır. Kar kalınlığı aynı aylarda sırasıyla 67 ve 146 cm'dir. Martta kar yağışının zayıflamasına karşın 138 cm'ye eriştiği gözlenir. Her iki istasyon arasındaki büyük farkın temel sebebi, İnebolu'da toplam yağış miktarının Cide'den fazla olmasıdır. Kastamonu'da kar yağışlı gün sayısı kıyı istasyonlarına göre iki kat daha fazladır. Karasal özellikten ötürü, kasımda başlayan karla kaplı günler nisan sonuna kadar devam eder. Kar kalınlığı İnebolu kadar değildir; ocakta $53 \mathrm{~cm}$, şubatta 47 cm'dir. Bu durum Kastamonu'da kar yağışı miktarının az olduğunu, fakat düşük sıcaklığa bağlı olarak bu yağışın uzun süre yerde kaldığını gösterir.

Sonuçta, inceleme sahasında kar yağışları özellikle kış mevsiminde görülmektedir. Kıyı şeridinde yer alan Cide ve İnebo- lu'nun, iç kesimde yer alan Kastamonu'ya göre kar yağışlı gün sayıları düşüktür. Yükselti arttıça ve kıyıdan iç bölgelere doğru gidildikçe kar yağışlı günlerin sayısı da artmakta, aynı zamanda karın yerde kalma süreleri uzamaktadır. Kıyı kesiminde kar kalınlığının daha fazla olmasına rağmen, yerde kalma süresinin kısalması denizel özellikle ilgilidir.

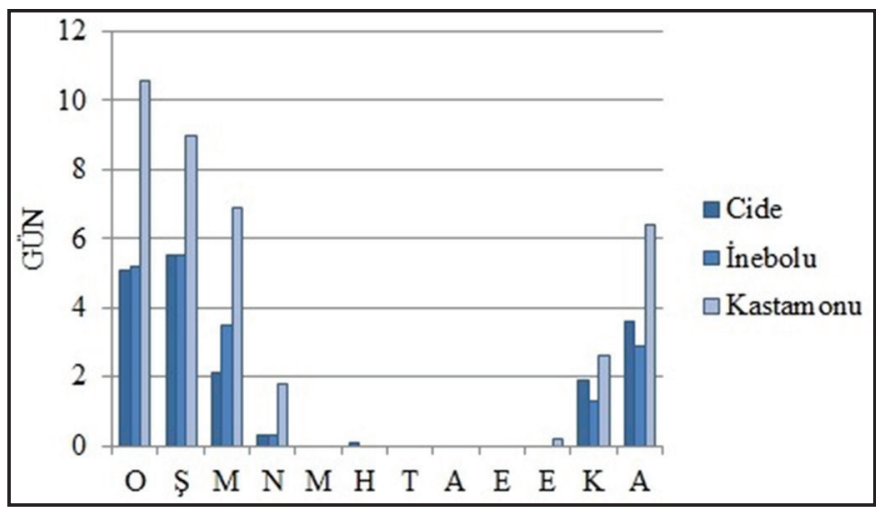

Şekil 15. İnceleme sahasında aylık ortalama kar yağışlı gün sayısı.

Figure 15. The mean monthly snowy days at the weather stations in the study area.

Dolu yağışı, şiddetli dikey hareketin hız kazandığı sıcak devrede, kümülonimbus bulutlarına bağlı olarak gerçekleşen bir yağıştır. Oraj ve sağanak yağışla birlikte meydana geldiği için zaman zaman afet boyutu kazanabilmektedir. Sel baskınları, tarım ürünü kayıpları ve hasarlarla birlikte yaralanma ve can kayıplarına yol açabilir. Kastamonu yöresi bu tür yağışların sık meydana geldiği merkezler arasında yer alır. Örneğin, 13 Eylül 2018'de Kastamonu'da meydana gelen dolu yağışında sel baskınlarının yanı sıra büyük miktarda hasar meydana gelmiştir (Coşkun, 2020 a). İnceleme sahasında dolu yağışları daha çok bahar ve yaz aylarında yoğunlaşır. Cide'de mart ayında başlayarak, aralık ayına kadar devam eder. İnebolu'da yılın bütün aylarında dolu riski vardır. Kastamonu da dolu yağışının kış ayları dışında bütün aylarda meydana geldiği görülür. Özellikle nisan $(0,6)$, haziran $(0,9)$ ile en çok dolu yağışlı güne sahiptir (Tablo 15, Şekil 16). Kastamonu'da diğer istasyonlara

Tablo 15. Cide, İnebolu ve Kastamonu'da dolu yağışlı gün sayıları.

Table 15. Number of the hail days at Cide, Inebolu and Kastamonu weather stations.

\begin{tabular}{|c|c|c|c|c|c|c|c|c|c|c|c|c|c|}
\hline İstasyon & 0 & $\mathbf{S}$ & $\mathbf{M}$ & $\mathbf{N}$ & $\mathbf{M}$ & $\mathbf{H}$ & $\mathbf{T}$ & A & $\mathbf{E}$ & E & $\mathrm{K}$ & A & Yıllık \\
\hline Cide & & & 0,1 & 0,1 & 0,1 & 0,1 & 0,1 & 0,1 & & 0,1 & 0,1 & & 0,8 \\
\hline İnebolu & 0,1 & 0,1 & 0,1 & 0,1 & 0,1 & 0,1 & 0,0 & 0,1 & 0,1 & 0,1 & 0,2 & 0,3 & 1,4 \\
\hline Kastamonu & 0,0 & 0,0 & 0,2 & 0,6 & 1,0 & 0,9 & 0,2 & 0,2 & 0,2 & 0,1 & & 0,0 & 3,4 \\
\hline
\end{tabular}


göre özellikle sıcak mevsimde dolu yağışlarının daha etkili olduğu görülmektedir. Bunun temel nedeni, karasal özellikten dolayı bu bölgede ilkbahardan itibaren başlayan aşırı ısınma ve buharlaşma, şiddetli dikey harekete yol açmaktadır. Ilgaz Dağlarının yamaçları boyunca hızlı yükselen hava kütlesi beraberinde dolu yağışını meydana getirmektedir.

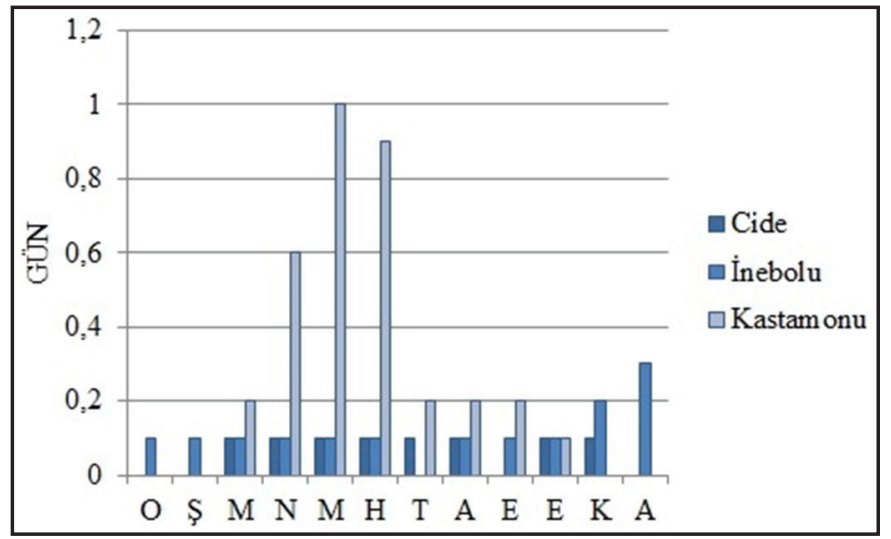

Şekil 16. Inceleme sahasında dolu yağışlı günlerin aylara göre değişimi. Figure 16. Hail days by months at the weather stations in the study area.

\subsubsection{Iklim tipi}

Cide ve Inebolu'nun Thorthwaite göre iklim tipleri birbirlerinin benzeridir, sadece derece farkı vardır. İnebolu'da $\mathrm{B}_{1} \mathrm{~B}_{1}{ }_{1} \mathrm{Sb}_{4}{ }_{4}$ harfleriyle, Cide'de ise $\mathrm{B}_{1} \mathrm{~B}_{2}{ }_{2} \mathrm{Sb}^{\prime}{ }_{3}$ harfleriyle ifade edilen nemli, mezotermal, su noksanı yaz mevsiminde ve orta derecede olan, deniz etkisine yakın iklim tipi görülür. Köppen'e göre her iki istasyon Cfa harfleriyle ifade edilen her mevsimi yağışlı, en sıcak ay ortalaması $22^{\circ} C^{\prime}$ nin üzerinde olan orta kuşak iklimleri arasındadır. De Martonne'un 1942'de ortaya koyduğu yıllık kuraklık indisi formülü her iki yere uygulandığında, nemli iklim bölgesinde olduklarını gösterir. Erinç sınıflandırmasında ise yıllık indis değerleri 30'un üzerinde olup, yarı nemli iklim sahasına girmektedir. İçerilere gidildikçe, yağışlarda azalma buharlaşma miktarlarında da artş̧lar meydana gelir. Karasal etkilerin kendini hissettirdiği Kastamonu; Thornthwaite'e göre, $\mathrm{C}_{1} \mathrm{~B}_{1}{ }_{1} \mathrm{db}^{\prime}{ }_{3}$ diye harfleriyle ifade edilen, kurak-az nemli orta sıcaklıkta, su fazlası pek az olan deniz etkili iklim tipine dahil olur. Köppen'e göre, Cfk' ya yakın görünüyor. De Martonne'ye göre indis değerleri itibariyle nemli grupta yer alır. Erinç'in yıllık indisleri 8-23 değer aralığında olduğu için yarı-kurak iklim bölgesi olarak ortaya çıkar (Coşkun, 2020 b).

\section{Sonuç}

Bat Karadeniz bölümünde bulunan Kastamonu ili, coğrafi konumu ve yerel şartları dolayısıyla kendisine has iklim özelliklerine sahiptir. Kastamonu'nun çeşitli yöreleri arasında, sınırları tamamıyla Karadeniz Bölgesi içerisinde yer almasına rağmen, iklim özellikleri bakımından belirgin farklar ortaya çıkar. Denize göre konum, dağların uzanışı, yükseklik farkı ve birbirine olan uzaklığı, bu farkları derinleştirir. Küre Dağları; Kastamonu şehri ve bir kısım ilçelerin yer aldığı geniş bir topografyayı, kıyı bölgesinden ayırır. Dağların engebeli yapısı kısa mesafede iklim elemanlarının farklılık göstermesine ve buna bağlı olarak mikroklima sahalarının oluşmasını sağlar. Bundan dolayı; kıyı, iç platolar ve dağlık alanlar, iklim özellikleri bakımından ayrı mıntıkaları oluşturur.

Inceleme sahasının iklimini etkileyen küresel şartların başında, güneş ışınlarının geliş açısı ve basınç merkezlerinin konumuna göre hareket eden hava kütleleri gelmektedir. İklimin devamlı suretle yağışlı olmasında, özellikle soğuk mevsimde uğrayan hava kütlelerinin payı büyüktür. Enlem değerleri, ılımanlık ve mevsim özelliklerinin oluşumunda önemli rol oynamaktadır. Genel şartlar, bölgenin sadece yer aldığı iklim kuşağını ortaya çıkarırken, esas kendi içerisindeki değişimin sebebi, Karadeniz'in varlığı ve Küre Dağlarının özellikleri olarak ortaya çıkmaktadır. Bu dağlar Kıyı kesimini Karadeniz iklim kuşağına dahil ederken, İç bölgeleri daha çok karasal iklim bölgelerine yakınlaştırmaktadır. Kıyıda belirgin olmayan sıcaklık farkları ve sıcaklık değerlerindeki iniş-çıkışlar, içeride belirginleşmektedir. Don olayları, artmasının yanı sıra bahar aylarına sarkmaktadır. Atmosferdeki nem değerleriyle birlikte bulutluluk seviyelerinde uyumsuzluk ortaya çıkmaktadır. Rüzgârların hızı, kıyıdaki istasyonlarda 2-3 misli daha fazla bir değere sahiptir. Yağış değerleri dağ engelini aşamadığından, iç kısımdaki platolarda yarı yarıya düşmektedir. Küre Dağlarının hemen güney yamacında başlayan yağış azalmasının yanı sıra, yağışın mevsimlere dağılışında da düzensiz bir durum görülmektedir. Bütün bunlar, kıyıdan görece çok uzakta bulunmayan içerideki plato ve havzaların iklim özelliklerinde, karasal etkileri açıkça ortaya çıkarmaktadır. Ayrıca iklim sınıflandırmaları bu durumu desteklemektedir. Cide ve İnebolu, Thornthwait'e göre; orta dereceden sıcaklığa sahip, su noksanı yaz mevsiminde ve orta derecede olan, deniz iklimine yakın iklim tipine girmektedir. Kastamonu ise; kurak az nemli, orta sıcaklıkta, su noksanı fazla olan deniz tesirli iklim tipinde yer almaktadır. Köppen formülü, kıyı istasyonlarını her mevsimi yağışlı, orta kuşak iklimlerine, iç kısımları ise kışları soğuk orta kuşak iklimlerine dahil etmektedir. De Martonne'ye göre her iki alan nemli iklim bölgesinde kalmasına rağmen aylık indislerde farklılık ortaya çıkmaktadır. Erinç'in değerlendirmesi sonucu iç kısımlar yarı kurak, kıyılar ise yarı nemli sınıfta yer almaktadır.

Bu duruma göre; kıyıda görülen tipik Karadeniz iklimi iç kısımlarda önemli değişikliklere uğrayarak, İç Anadolu karasal iklimine, bazı yerlerde Doğu Anadolu karasal iklimine benzemektedir. Hatta yıllık ortalama sıcaklık, her iki iklim tipinin altında bir değer göstermektedir. Yıllık sıcaklık farkı İç Anadolu karasal iklimine yakındır, fakat yıllık ortalama yağış miktarı ve yaz yağışları oranı biraz artıp Karadeniz iklimine yaklaşmıştır. Yağış değerleriyle Doğu Anadolu, sıcaklık değerleriyle İç Anadolu karasal iklim tiplerini hatırlatmaktadır. Ancak, yağış ve sıcaklık rejimi olarak bu iklim tiplerine göre daha düzenli bir seyir takip etmektedir. 


\section{Kaynakça}

Coşkun, M., \& Akbaş, V. (2017). Karadeniz kıyısından iç kesime: Kastamonu çevresinin iklim parametreleri. Sosyal Bilimler Dergisi, 4 (11), 46-86. http://dx.doi.org/10.16990/SOBIDER.3486

Coşkun, S. (2020 a). 13 Ey/ül 2020 tarihindeki dolu yağışının Kastamonu çevresine etkileri. İçinde Nigmatov, A. (Ed), (ss. 44-50). Global Science and innovations 2020- Eurasian Center of İnnovative Development Dara.

Coşkun, S. (2020 b). Kastamonu ve çevresinin iklim sınıflandırmalarındaki yeri. İçinde Akbaş, F., Atş, E. (Ed), (ss. 201-220). 21. Yüzyılda Türkiye Coğrafyası Araştrrmaları. Gazi Kitabevi.

Dönmez, Y. (1984). Umumi klimatoloji ve iklim çalışmaları. İstanbul Üniversitesi Coğrafya Enstitüsü Yayınları.

Dönmez, Y. (1985). Bitki coğrafyası. İstanbul Üniversitesi Coğrafya Enstitüsü Yayınları.
Duran, C. (2017). Kastamonu ili ve yakın çevresinde sıcaklığın ve yağışın yöresel dağılımı. Uluslararası Sosyal Araştırmalar Dergisi, 10 (52), 509-517. http://dx.doi.org/10.17719/iisr.2017.1911

Erinç, S. (1984). Klimatoloji ve metodları. İstanbul Üniversitesi Deniz Bilimleri ve Coğrafya Enstitüsü Yayınları.

Erol, O. (1999). Genel klimatoloji. Çantay Kitabevi.

Kurter, A. (1971). Kastamonu ve çevresinin iklimi. İstanbul Üniversitesi Coğrafya Enstitüsü Yayınları.

Kurter, A. (1982). Kastamonu ve çevresinin doğal görünümü. İstanbul Üniversitesi Edebiyat Fakültesi Yayınları.

Meteoroloji Genel Müdürlüğü (2016). Meteorolojik rasatlar. Orman ve Su İşleri Bakanlığı Meteoroloji Genel Müdürlüğü.

Tuğ, R. (2006). Cide çevresinin iklimi ve çevresel etkileri (Yayın no: 214915),[Yüksek lisans tezi, İstanbul Üniversitesi] YüksekÖğretim Kurulu Başkanlığı Tez Merkezi. https://tez.yok.gov.tr/UlusalTezMerkezi/ 